\title{
The Impact of Feed Supplementations on Asian Buffaloes: A Review
}

\author{
Amirul Faiz Mohd Azmi ${ }^{1}\left({ }^{1}\right.$, Hafandi Ahmad $^{1}\left(\mathbb{D}\right.$, Norhariani Mohd Nor $\left.{ }^{1} \mathbb{(}\right)$, Yong-Meng Goh ${ }^{1}(\mathbb{D}$, \\ Mohd Zamri-Saad ${ }^{2}\left(\mathbb{D}\right.$, Md Zuki Abu Bakar $^{1}$, Annas Salleh ${ }^{2} \oplus$, Punimin Abdullah ${ }^{3}$, Anuraga Jayanegara ${ }^{4,5}(\mathbb{D}$ \\ and Hasliza Abu Hassim 1,5,6,*(1)
}

\section{check for}

updates

Citation: Mohd Azmi, A.F.; Ahmad, H.; Mohd Nor, N.; Goh, Y.-M.; Zamri-Saad, M.; Abu Bakar, M.Z.; Salleh, A.; Abdullah, P.; Jayanegara, A.; Abu Hassim, H. The Impact of Feed Supplementations on Asian Buffaloes: A Review. Animals 2021, 11, 2033. https://doi.org/10.3390/ ani11072033

Academic Editors: Maria de la Luz Garcia, María-José Argente and Frank van Eerdenburg

Received: 4 May 2021

Accepted: 3 June 2021

Published: 7 July 2021

Publisher's Note: MDPI stays neutral with regard to jurisdictional claims in published maps and institutional affiliations.

Copyright: (c) 2021 by the authors. Licensee MDPI, Basel, Switzerland. This article is an open access article distributed under the terms and conditions of the Creative Commons Attribution (CC BY) license (https:/ / creativecommons.org/licenses/by/ $4.0 /)$.
1 Department of Veterinary Preclinical Sciences, Faculty of Veterinary Medicine, Universiti Putra Malaysia, UPM Serdang, Serdang 43400, Malaysia; amirulfaizazmi@gmail.com (A.F.M.A.); hafandi@upm.edu.my (H.A.); norhariani@upm.edu.my (N.M.N.); ymgoh@upm.edu.my (Y.-M.G.); zuki@upm.edu.my (M.Z.A.B.)

2 Department of Veterinary Laboratory Diagnosis, Faculty of Veterinary Medicine, Universiti Putra Malaysia, UPM Serdang, Serdang 43400, Malaysia; mzamri@upm.edu.my (M.Z.-S.); annas@upm.edu.my (A.S.)

3 Faculty of Science and Natural Resources, Universiti Malaysia Sabah, Jalan UMS, Kota Kinabalu 88400, Malaysia; puniminabdullah@ums.edu.my

4 Department of Nutrition and Feed Technology, Faculty of Animal Science, IPB University, Bogor 16680, Indonesia; anuraga.jayanegara@gmail.com

5 Animal Feed and Nutrition Modelling (AFENUE) Research Group, Department of Nutrition and Feed Technology, Faculty of Animal Science, IPB University, Bogor 16680, Indonesia

6 Laboratory of Sustainable Animal Production and Biodiversity, Institute of Tropical Agriculture and Food Security, Universiti Putra Malaysia, UPM Serdang, Serdang 43400, Malaysia

* Correspondence: haslizaabu@upm.edu.my; Tel.: +60-3-9769-3417

Simple Summary: Apart from feeding with forages, dietary supplementation with concentrate and rumen bypass fat is one of the feeding strategies to enhance nutrient availability and improve buffalo performance and productivity. This review paper thoroughly discussed the utilization of concentrate and bypass fat as dietary supplementation in buffalo feeding, and discussed the effects on performance, fermentation characteristics and general health of buffaloes to give better insight about the potential and challenges of dietary supplementation in buffalo diet. Based on the literature studies, it can be summarized that supplementation of concentrate and bypass fat in buffaloes may overcome the nutritional problems and improve the growth performance, health status, rumen environment and carcass traits.

Abstract: With the increase in the global buffalo herd, the use of supplementation in the ruminant feeding has become an important area for many researchers who are looking for an isocaloric and isonitrogenous diet to improve production parameters. In order to improve the performance of the Asian water buffalo, the optimal balance of all nutrients, including energy and protein, are important as macronutrients. Dietary supplementation is one of the alternatives to enhance the essential nutrient content in the buffalo diet and to improve the rumen metabolism of the animal. Researchers have found that supplementation of concentrate and rumen bypass fat could change growth performance and carcass traits without causing any adverse effects on the buffalo growth. Some studies showed that dry matter intake, body condition score and some blood parameters and hormones related to growth responded positively to concentrate and rumen bypass fat supplementation. In addition, changes of feeding management by adding the supplement to the ruminant basal diet helped to increase the profit of the local farmers due to the increased performance and productivity of the animals. Nevertheless, the effects of dietary supplementation on the performance of ruminants are inconsistent. Thus, its long-term effects on the health and productivity of buffaloes still need to be further investigated.

Keywords: bypass fat; buffalo; concentrate; performance; supplementation 


\section{Introduction}

The Asian water buffalo (Bubalus bubalis) is an important animal resource in a minimum of 67 developing countries. Many people rely on this species for their livelihoods [1]. It provides economic value from its meat, milk and leather, and especially draft power [2]. An estimation by Scherf [3] revealed that more than 2 billion people depend on approximately 200 million heads of buffaloes, which is more than any other domesticated animal. The majority of buffaloes operate in close association with humans on small farms, for whom these animals are also their largest capital asset. Based on morphological and behavioral criteria, there are two subspecies of domesticated water buffaloes, the swamp (Bubalus bubalis carabanesis) and the river or Murrah (Bubalus bubalis bubalis) buffaloes [4,5]. Crossbreds between Murrah and Swamp (Bubalus sp.) buffaloes are found in some parts of Asia, especially in China, Indonesia, the Philippines, Thailand, Vietnam and Malaysia [6].

Currently, buffalo management practices are intrinsically correlated to the status of buffalo health, production and welfare. In order to ensure the optimum health of the animals and the organized production of high-quality and safe animal products (meat, milk and dairy products), a proper diet ration arguably represents the easiest strategy that can be implemented by farmers at the farm level. Both the meat and the dairy buffalos industries have made significant advances in animal management, husbandry, genetics and nutrition. However, the current climate change phenomenon has caused a reduction of the availability of rangeland pastures and forages, especially for animals reared under the free-grazing system [7]. According to Henry et al. [8], extreme and fluctuating temperature may impair the optimum health and quality of life of animals. Furthermore, changes of the economic patterns around the world due to COVID-19 issues and the increasing demand for livestock as well as animal products from the developing countries trigger all the stakeholders involved in ruminant production to reconsider the strategic use of nutrition for enhancing animal health and production. Indeed, the livestock industry must find alternative nutritional strategies which meet the demand of consumers for economical animal products that are produced in clean, halal, green and ethical manners [9]. From our literature review, we found an abundance of scientific trial studies on animals (in vitro and in vivo) that indicated reliable and cost-effective approaches for increasing ruminant profitability through optimizing the composition of the feed nutrients and with the addition of supplementation [7].

Nowadays, the buffalo industry in Malaysia is starting to gain some attention as there are currently more studies on buffalo production, especially on how to improve it. This is in line with what has been carried out elsewhere, especially in other Southeast Asian countries. We therefore propose an approach using a suitable diet of a combination of basal diet with supplementation aimed for growing buffaloes. Hence, in this review article, we discussed the challenges of the buffalo industry, the requirements for energy and protein for buffalo growth, the potential of supplementation in the buffalo diet and the effects of the supplemented diet on rumen fermentation characteristics, growth performance, quality of the buffalo meat and the economics of the feed ration in ruminants. Our findings would allow specific dietary supplementation-based strategies to be established, which could efficiently enhance the health, welfare and longevity of the buffalo.

\section{Characteristics of Asian Water Buffalo}

\subsection{Morphology and Genetics}

In the field, river and swamp buffaloes can be differentiated based on their morphology and behavior. Swamp buffaloes are ash or dark grey with a white chevron line on the neck, either one or two stripes, and have socks, while the tip of the tails and the horns are swept backwards $[10,11]$. They prefer to wallow in the marshland and mud, and have large feet with slow steady movement that make them well-suited for paddy land preparation in swampy waterlogged rice fields [12]. On the other hand, river (Murrah) buffaloes have black bodies with tightly and forwardly curled horns. They prefer to wallow in clean 
water [10]. The crossbred buffaloes have the same morphology as the Murrah but are smaller than the Murrah and bigger than the Swamp buffaloes.

The chromosome number also differs between Swamp and Murrah, with river $2 \mathrm{n}=50$ and swamp $2 n=48$ [11], owing to the fusion of chromosomes $4 p$ and 9 [13]. The river and swamp buffaloes are also genetically distinct, as confirmed by the variations in allozymes, sex-linked, autosomal DNA markers, mitochondrial DNA sequences, microsatellite variation and a comparison with protein-coding loci $[11,14,15]$. Malaysian swamp buffaloes from the peninsula and Borneo region such as Sabah and Sarawak states were studied in this work. The peninsular and the Borneo swamp buffaloes were found to be genetically distinct, hence paving the way for the possibility of crosses between them to improve the Malaysian swamp buffaloes [6]. In addition, a prior study in Malaysia had reported that phylogenetic tree and mtDNA analysis on Swamp buffaloes were genetically conserved and the crossbreds were dominantly Swamp according to the maternal lineage using d-loop mtDNA [6].

On the other hand, crossbred buffaloes are the result of a combination of the two genetic types, but showing $80 \%$ dominant characteristics of the Murrah breed [6]. Crosses between river and swamp buffalo are fertile, despite having $2 n=49$ chromosomes in $F_{1}$ and $F_{2}$ offspring. The crossbred buffaloes show better growth, larger body size and much improved draft power compared to the local swamp buffaloes [16]. Furthermore, the crossbred buffaloes are capable of yielding extra milk production, with an average of between 4.0 and $1.94 \mathrm{~kg} /$ day [17]. In fact, crossbred buffaloes are much more improved in terms of birthweight, age at maturity and first calving, duration of heat and period of inter-calving [18]. Indeed, with improved feeding, the crosses were recorded to grow $40 \%$ faster, with significantly improved meat quality than the Swamp buffaloes [19].

\subsection{Distribution and Use}

The indigenous breed of buffalo in East and Southeast Asia is the Swamp buffalo (Bubalus bubalis carabanesis). It is largely concentrated in Southeast Asia and Southern China (Figure 1). In China, the Swamp buffaloes have adapted to a range of climates, altitudes and temperatures [20]. Therefore, the Swamp buffaloes could be found in both low- and high-lands. Traditionally, the Swamp buffalo is used mainly for draught power, particularly for ploughing paddy fields and transportation, but it is also used to supply meat for human consumption. Until now, some oil palm estates are still using Swamp buffaloes as draught animal to pull carts carrying oil palm bunches. Occasionally, Swamp buffaloes' milk is used to make dairy products such as yoghurt and mozzarella cheese.
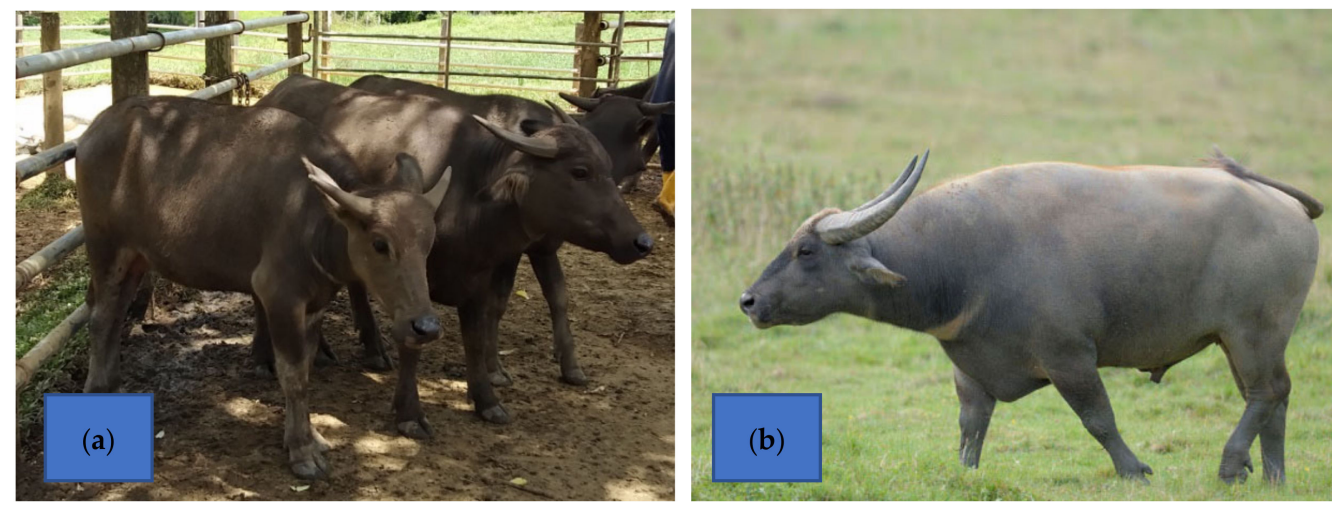

Figure 1. The swamp buffaloes. (a) Calves Swamp buffalo, (b) adult Swamp buffalo. Reprinted with permission from ref. [21]. Copyright 2021 Mohd Azmi et al. 
River or Murrah buffaloes (Bubalus bubalis bubalis) are mainly found in South Asia, with the highest distributions in Pakistan, India, the Middle East and Italy (Figure 2). They are primarily reared for their milk typified by the high contents of fat and dry matter. Furthermore, buffalo milk has lower cholesterol content, but compared to cow's milk, it has more calories and fat. Thus, it is used to produce high-value thick and creamy cheese, yoghurt and ghee [20]. Murrah buffaloes are also used to improve buffalo milk production in many other countries such as Egypt and Bulgaria [22]. According to Hamid et al. [23], the Murrah buffaloes have been described as the "Asian tractors" and serve the purpose of meat, milk and work. In contrast to the Swamp buffaloes, river buffaloes are more aggressive, with temperamental instability [24].
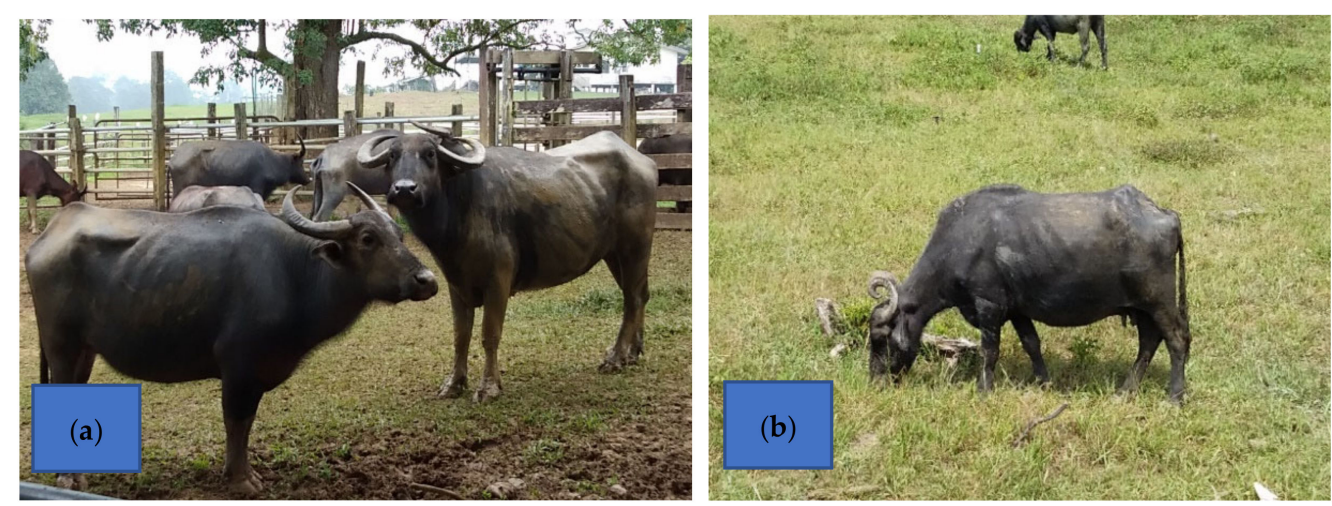

Figure 2. The crossbred and pure-bred Murrah buffaloes. (a) Crossbred buffalo and (b) pure-bred Murrah buffalo. Reprinted with permission from ref. [21]. Copyright 2021 Mohd Azmi et al.

The multipurpose crossbred buffaloes are mainly found in several parts of Asia, especially in China, Indonesia, the Philippines, Thailand and Vietnam. They are used to provide draught power and meat in rice-growing areas and milk in other regions [25]. Now, crossbreeding of buffaloes is practiced in almost all countries where Swamp buffaloes are found, such as China, Burma, Thailand, the Philippines, Malaysia and Sri Lanka, with the aim of improving the milk yield and the animal size for work in the field [26].

\section{Challenges in Buffalo Production Systems}

An alarming decline in the buffalo population of Southeast Asia has happened over the past two decades at an average rate of 1.2 percent per year. This is due to several factors: (i) poor market demand for buffalo products [27], (ii) high rate of slaughter coupled with insufficient input for research and development [28], (iii) increased agricultural mechanization that made the Swamp buffalo redundant, (iv) a myth against the quality of buffalo meat [29], (v) poor reproductive performance coupled with poor responses to the biotechnology currently available, such as embryo transfer technology and artificial insemination, which prevented sufficient proliferation of the buffalo [17], and above all, (vi) a lack of knowledge on farm and feed management, resulting in a rapid decline in the number of buffaloes.

Furthermore, a few other factors have been cited as possible constrains that had contributed to the low output from beef and mutton producers. These factors include the inadequacy of land suitable for grazing to sustain significant livestock breeding populations, low supply of quality breeding stocks, erratic supply of high nutritional value feed and lack of an effective system of marketing. Taking cues from the poultry industry, the beef industry must promote ready supplies for the breeding and fattening of the production stock, ensuring the continuous supply of reasonably priced buffalo feed and creating an effective marketing network [30]. 
In Asia, in accordance with the environment, soil and socioeconomic opportunities, buffalo production systems vary widely [31]. The semi-intensive production system practiced by smallholder farmers is currently focused upon by many developing countries for the ruminant industry, mainly for cattle and buffalo. According to Saadullah [31], buffaloes in Asia that are mostly under the semi-intensive system are kept mainly for specific purposes, such as for meat and milk production. Approximately, $11 \%, 5 \%$ and $84 \%$ of the smallholder farmers reared buffalo for milk, meat and for both milk and meat, respectively [32]. Recently, the extensive production system is used through integrating ruminants, including buffaloes with oil palm or rubber plantations [30], where large-scale pasture lands and green forages or grasses are available [33] that allow the animals to graze for an average of 6 to $8 \mathrm{~h}$ daily [34]. However, most buffalo farms practice the semiextensive grazing system in oil palm or paddy field areas without supplementation [35].

South and Southeast Asia have many marshlands and rivers which are suitable for raising buffaloes. Moreover, improvements in feeding management have influenced the growth performances of buffaloes in countries such as India, Brazil, the Philippines and Malaysia $[35,36]$. In general, indigenous Swamp and crossbred buffaloes in Southeast Asia are low in numbers, and this has affected the production of dairy and meat. Furthermore, longer puberty age, seasonality of breeding, longer calving interval, high calf mortality and poor genetic pool, nutrition and management practices [37-39] have all influenced the productivity.

\section{Feeding and Nutritional Management for Buffalo Production}

\subsection{Nutrient Requirements and Utilization of Buffalo}

Like other ruminants, buffaloes obtain their energy and protein in the form of volatile fatty acids and microbial proteins from fermentation end products. Based on research studies on the nutritional requirements and digestive physiology of buffaloes, it was concluded that buffaloes underwent relatively higher ruminal degradation of both protein and fiber [40] as compared to cattle [41]. This unique ability, particularly the better fermentation of fibers in buffaloes in temperate countries, is the consequence of adaptation following years of being fed with low-quality and highly fibrous diets [42]. According to Manish [43], the protein and energy demands of buffaloes in Asia were being met by feeding roughages containing high levels of lignocellulosic materials, namely cellulose, hemicellulose, lignin and low levels of fermentable carbohydrates and proteins. Indeed, the irregular and inadequate availability of quality feedstuffs and their utilization had been reported as the main causes of the poor performance of buffaloes in Asia [44]. In contrast, developed countries that produce a large number of meat and dairy animals place much emphasis on improving energy and protein levels of animal feed as well as on developing a specific model of nutrient requirements in buffaloes. These were reported by various studies, where the levels of energy and protein requirements varied in buffalo diets during lactation and growth $[41,42,45]$. Nevertheless, limited strategic studies were performed to establish the protein and energy needs of buffaloes in Asia, particularly on assessing their effects on different physiological stages and on the performances of buffaloes of various breeds.

In general, buffaloes need optimal nutrient requirements such as protein, fat, vitamins, minerals and water in order to maintain life, to reproduce and to enhance productivity. These requirements are influenced by many factors [46,47]. They include:

1. Animal-based factors, such as the physiological status (growth), age and body weight of animal, production line, traits of digestive system and health status [48,49].

2. Ration-associated factors, including the feeds that are used in the ration and the nutritional, physical and chemical composition status of the feed [50].

3. Environmental-related factors, particularly the climate, air temperature and feeding system [51]. 
Currently, there is paucity of information regarding the energy requirements of growing, breeding, lactating or working buffaloes [52]. Therefore, the nutrient requirements for cattle have always been adopted for buffalo feeding following the recommendations by NRC [53] and AFRC [54].

Energy is typically derived from carbohydrates, namely starch, cellulose and fat [47]. The nature of the buffalo digestive system physiology makes the cellulose in roughages, a rather cheap energy source, important [55]. The recommended values of energy requirements for buffaloes differ depending on their stages and physiological conditions. Estimations of the energy requirements of buffalo gain in the literature varied from 0.78 to $2.23 \mathrm{TDN} / \mathrm{g}$ gain [52], and for the lactating stage it was $1.97 \mathrm{TDN} / \mathrm{g}$ gain [48]. In addition, the amounts of feedstuffs offered to buffaloes to meet their requirements were also linked to various characteristics, such as the type, quantity, quality and presentation of the feed [52]. Therefore, besides feeding with low-quality roughage, the high demand for energy by growing buffaloes should be fulfilled by supplementing with a mixture of quality roughage and grains that contained an abundance of energy [56]. Furthermore, adequate supplementation of fat was capable of increasing the concentration of energy in the animals, which could also enhance the percentage of fat in the milk as well as the quality of the meat [57].

Protein is an important substance for growth and development of muscles, nerves and other tissues. It is also important for the repair of aged tissues, fetus development and the production of meat and milk [58]. Ammonia is required for the growth of rumen microorganisms before optimal microbial protein synthesis is achieved by supplementation with adequate levels of protein and non-protein compounds [59]. Other studies reported earlier that there was a large variation in the values for protein requirements in buffaloes [48,52]. The estimated range of digestible crude proteins needed by buffalo for maintenance and growth was 1.11 to $5.05 \mathrm{~g} / \mathrm{kg}$ metabolic body size ${ }^{0.75}$ and 0.30 to $0.45 \mathrm{~g} / \mathrm{g}$ gain, respectively [52]. Following a low level of protein or energy supply to buffaloes, the demand for proteins was met by a low supply of medium-quality pastures and fodder. Therefore, growing, pregnant and lactating buffaloes should be fed with meadow grass and leguminous forage supplemented with concentrate, grain or oil seed cakes [46]. This could prevent protein insufficiency that might lead to declines in appetite and feed consumption of the animals, a negative utilization of feed and a reduction in cellulose digestion [55].

\subsection{Roughage Feeding}

It is clear that buffaloes' main diet consists of roughages such as grass, legumes and straw. Most of the buffaloes are fed on tropical grasses as the primary source of nutrients. The roughages are fed either fresh as the grazing pasture or dried such as in a cut and carry system or conserved as hay or silage. Thus, a relatively low cost of digestible energy from grasses is provided to the buffaloes, mainly in the form of fibrous compounds [60]. Nevertheless, the roughage that forms the basis of a feed ration should be of good quality, have both nutritional and hygienic qualities and be capable of meeting at least the total maintenance requirements. Unfortunately, tropical grasses for grazing buffaloes infrequently represent a balanced diet, since they have constraints on one or more nutrients that may limit the intake of forage, digestibility or the metabolism of the absorbed substrates [61]. Therefore, an addition of concentrate in the diet should be practiced in buffaloes' feeding to ensure a balanced ration, and nutrients are provided to meet the buffaloes' requirements [62].

To improve buffalo performance, the utilization of pastures in any season as the main nutrients is not considered to be optimal [61]. Thus, selecting mature, dried foliage and stems of grasses ensures supply of a low protein level of less than three percent of crude protein. Furthermore, the grasses have been variably leached of soluble components, including minerals, proteins, sugar and starchy carbohydrates that are needed for efficient fermentative digestion in ruminants. On the other hand, too much intake of non-fibrous 
feed can change the environment of the rumen, and in the long term, leads to serious feed digestion problems, including reducing feed intake, which leads to ketosis, weight loss and a reduction in milk yield. According to Figueiras [61], unbalanced energy to protein ratios were recorded in tropical grasses, with relative energy surplus. Thus, the use of this poor-quality forage without a supplementary diet contributed to the low production of the ruminant meat industry in developing countries. In fact, a study in Brazil and Australia revealed that using a proper feed supplementation program improved the body weights of ruminants [60]. For this reason, there is a need to recognize tropical pastures as having limitations of nutrients and to solve this or to change to feeding regimes that may lead to improved performances of the animals and the overall production efficiency [63].

\subsection{Supplementation Strategy}

Low growth performance, poor reproductive performance and milk yield have been reported in buffaloes in other studies $[64,65]$. Indeed, the poor performance reported by those studies correlated with poor dry matter intake and weight gain and longer calving intervals [64,65]. In many parts of Asia, inadequate and irregular availability of quality feedstuffs and their utilization are the main causes of the poor performance of buffaloes [44]. A report stated that buffaloes in Southeast Asia were mainly fed with hay or forages high in lignin and low in fermentable protein and carbohydrate contents [44]. Many strategies have been trialed in order to improve the nutrient supply and utilization in buffaloes, with varying degrees of success. These are: (1) utilization of available feed resources such as local plants that have high crude protein or energy content, (2) use of industrial and agricultural by products, (3) dietary addition of concentrate, fermentation modifiers and vitamins and (4) usage of ruminally protected dietary fat and protein sources, which have shown significant potentials to improve growth, reproduction and milk yield of buffaloes [44]. However, in order to choose the best strategy to improve buffalo performance, the farmer should identify the main problem causing the low growth performance of the animal.

In the buffaloes' diet, the roughage should often be complemented with concentrate, grains or agro-industrial products as supplements. The supplements should be fed only to fulfil the additional requirements for improving growth, pregnancy and milk production. Therefore, feed supplementation programs should concentrate mainly on the establishment of a diet that contains balanced nutrients by increasing the energy content in the diet as well as by increasing the dry matter intake through the addition of supplements. Indeed, a supplemented diet in the tropics should focus primarily on protein and fat supplementations in order to provide optimum energy for better growth performance of the animals $[63,66]$. This would allow for utilization of the relative excess of energy from the supplemented diet to be converted into body weight gain [67]. Balancing the fat and protein nutrition through supplementation is one of the strategies for increasing production in ruminants with high-energy diet requirements, such as young post-weaning animals, animals in the last trimester of pregnancy and lactating animals.

In most regions of developing countries, it is not practical to identify the deficient micronutrients and macronutrients in pastures or other forages, as these vary from site to site and year to year. Furthermore, they are also influenced by the pattern of fertilizer application and the weather conditions. The alternative is through providing buffaloes with a supplemented diet, and the supplementation involves providing energy and protein to satisfy the requirements for efficient digestion in the rumen. Diet with a proper supplementation is able to provide optimal ammonia nitrogen and good fatty acid in the rumen. Palatable and tasty feed with a well-balanced ratio of protein and fat as additional energy sources is the best way to increase milk production and live weight, maintaining health and enhancing fertility. This has influenced the changes in supplementation utilization, since a lack of knowledge on feeding management would affect animal production and nutritional performance $[63,66]$. However, comparative analyses regarding the combination of energy and protein supplementation on buffalo performance in the tropics remain scarce. Therefore, extensive studies are needed to assess the impacts of supplements on 
grazing buffaloes in the tropics, particularly on the intake, ruminal fermentation pattern and the quality of the meat.

\subsection{Types of Supplementation in Buffalo Diets}

Supplemented feed offers a promising way to enhance the overall health and performance of buffaloes. In contrast to a nutritionally complete ration, supplemental diets are intended to provide an additional source of energy and protein when forage quantity and quality are inadequate to meet the desired performance [68]. Nutritional husbandry of domestic buffalo often contains high energy and protein supplements in combination with roughage to increase the growth rate of sub-adult animals [69] and to enhance the digestibility of forage diets [70]. Supplementation strategies are essential in designing the feeding programs for this species. In fact, supplementation with larger amounts of energy-rich feeds with a source of protein and fat could reduce the time taken to prepare buffaloes for the market, thus increasing profitability, such as those reported for cattle that consumed low-digestibility forages with energy and protein supplements [71].

Concentrate is one of the dietary supplements that supply protein to animals. Many experiments have demonstrated the benefits of supplementing dietary protein meals or concentrate to ruminants that are fed poor-quality forage [72-74]. In fact, in developing countries, low cattle and buffalo productions are primarily due to limited supplies of nutrients in high forage-based rations [75]. Therefore, it is important to identify new feed sources and technologies for cattle and buffalo production systems. Recently, there are several varieties of concentrate ingredients that have been used by smallholder farmers, namely maize meal, cassava powder, rice bran and mixtures of these feedstuffs in ruminant production [75], such as cattle and buffalo. However, due to inadequate information on the nutritional value, digestibility and characteristics of the rumen fermentation, the benefits of using these feeds for buffalo are not well-understood. This is especially true since previous studies had reported that different proportions of concentrate feeds differed substantially in their rumen fermentation characteristics [76]. Nevertheless, a high starch content in the concentrate is important in ruminant nutrition because it is cost-effective, contains protein sources and has been proven able to influence rumen function and digestion of nutrients $[77,78]$.

The technology of bypass nutrients such as rumen bypass fat has been implemented in feed management through passive rumen manipulation [79]. It is also known as rumenprotected fat, inert fat or rumen bypass fat [80]. Bypass fat is the supplement that escapes rumen degradation as it is being protected from microbial fermentation, biohydrogenation and remains insoluble at normal rumen $\mathrm{pH}$. However, it is easily digested and absorbed in the lower gastrointestinal tract at the abomasum and small intestine, respectively [81]. Therefore, it might be beneficial for ruminants to be fed with rumen bypass fat as a supplementary diet that is absorbed readily from the lower digestive tract. There are two types of rumen bypass fat supplements commercially used by farmers, namely natural bypass fat (e.g., cotton, roasted soybeans, sunflower and canola whole oil seeds) and chemically prepared bypass fat (e.g., crystalline or prilled fatty acids, formaldehyde-treated protein-encapsulated fatty acid, fatty acyl amide and calcium salts of long-chain fatty acids) [82]. The calcium salt-coated method on fatty acid of vegetables has been reported to be a more accessible bypass fat to all types of farmers. It has also been proven to be a cost-effective technology compared to other rumen bypass fats [83]. A few studies reported improvements on the growth and nutrient utilization of buffalo calves after being fed with bypass nutrients $[84,85]$. Integration of fat supplement into the diet enhances the growth potential of buffalo calves [79]. Studies have reported that high fat supplementation, such as RPF, could also enhance fiber digestibility of various fibrous feedstuff due to the high hydrolysis rate in rumen $(85 \%$ to $95 \%)[81,82]$. This supplement can also improve energy efficiency, as a result of reduced production of methane from the rumen and direct use of long-chain fatty acids [86]. Many studies recommended that the ration of high producing and growing animals should contain between $3 \%$ to $6 \%$ fat in the total ration DM, in 
order to obtain the beneficial effects [82]. Meanwhile, feeding more than $9 \%$ rumen bypass fat would not be beneficial for the growth (feed intake) and lactation (milk yield) of the animals [82].

\section{Effect of Dietary Supplementation on Buffalo Production}

The advantages of high energy and protein in dietary supplements can be the explanation for the improvements in the growth and fattening of ruminants. Indeed, it has been shown that apart from improvement of the growth performance upon supplementation of concentrate and bypass fat, the improvement in dry matter intake may further enhance the average daily gain, growth hormones (e.g., GH and IGF-I), body condition score, carcass traits, meat quality and breeding performance of buffaloes [21,79,87]. In addition, the supplementation of both concentrates and bypass fat did not cause any adverse effects on serum biochemical profiles, rumen fermentation and microbial population [21,28,33-35]. An overview of the role of these concentrate and bypass fat supplementations in buffalo nutrition is presented in Figure 3.

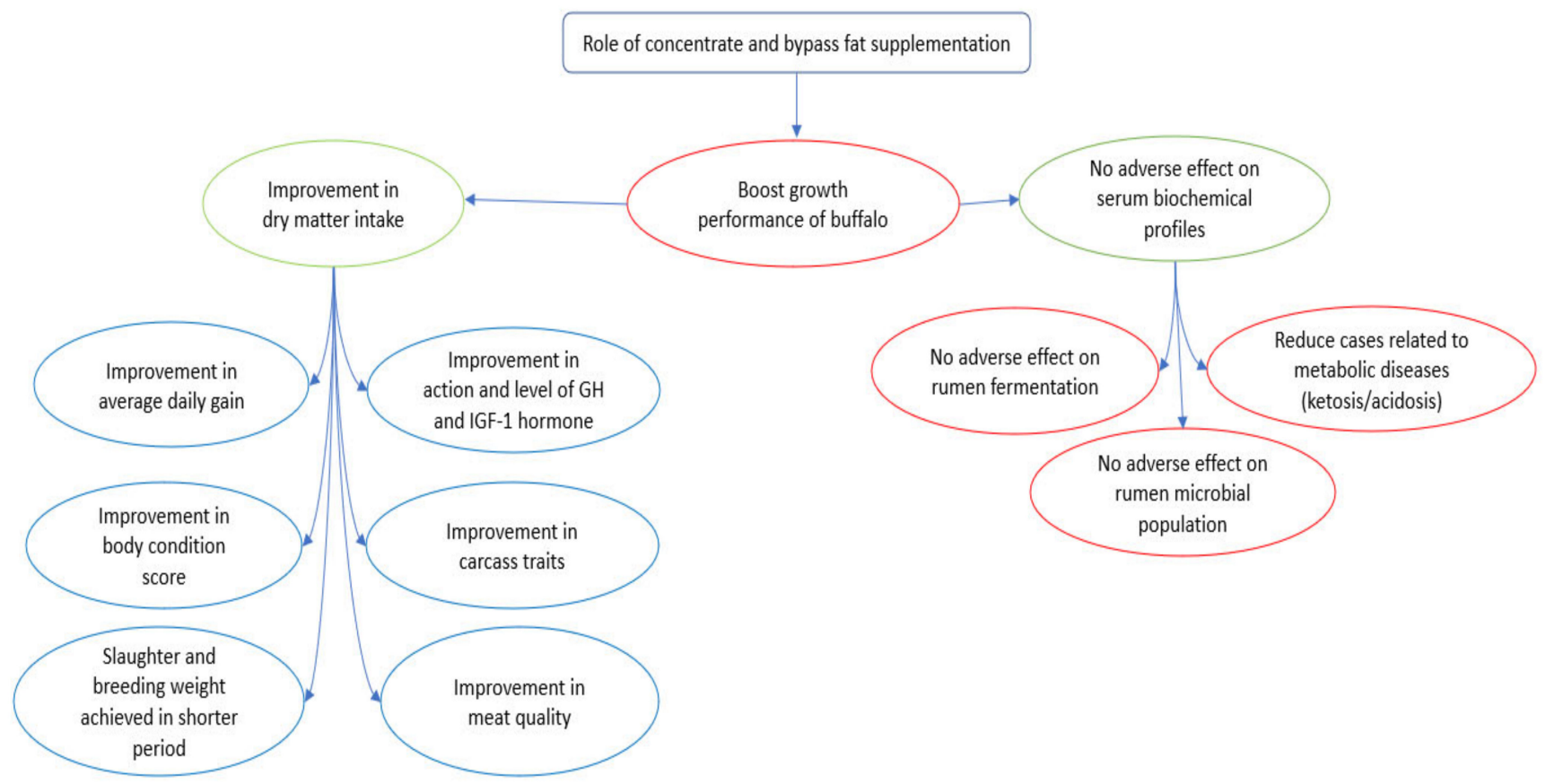

Figure 3. An overview of the role of concentrate and bypass fat supplementation in buffalo nutrition.

\subsection{Growth Performance}

The body weight gain and the body condition score (BCS) of buffalo calves after weaning represent the growth vigor of the animal. This is a substantial feature in the selection of animals [88]. The body condition score of a buffalo is classified as a subjective scoring method to assess the outer appearance of the animal, which interacts with its body fat to provide a better understanding of the biological relationships between body fat, reproductive performance and production of milk. These could assist in the implementation of optimal management practices to achieve maximum production and to preserve better health status [87]. Indeed, the BCS may also provide an immediate evaluation of the body condition of the animal and can be readily integrated into operational decision-making [89]. The use of BCS started in studies of ewes, beef cattle and Holstein dairy cows in 1961, 1976 and 1989, respectively. It used a 0 to 5 scale with a chart developed for references of body condition scoring [87]. In Pakistan, there was a study on Nilli Ravi buffalo that assessed the BCS by using a linear scale of 1 to 9 (1-3 for thin, 4-6 for average and 7-9 for fat), where the scoring was performed visually by assessing the covering of fat over the tail head, rump, 
sacral bone and loin and withers area [90]. However, the BCS of buffaloes was improved and established in India [87] using a 1 to 5 scale for assessing the animals (Figure 4). India has the highest buffalo population in the world and shows dramatic increases of population numbers yearly [91]. In addition, it is the native tract for the best buffalo breeds of the world [92]. The improved chart for BCS of buffalo with a 1 to 5 scale using 0.25 increments has been widely used in Asian countries [92]. The BCS score assessment was carried out by taking into consideration the anatomical features and amounts of fat reserves at various skeletal checkpoints. Validation of the precision of the BCS score had been carried out via ultrasonic measurements of subcutaneous fat [92]. Thus, the use of the BCS 1 to 5 score is suitable for assessing the reproduction and production status of buffaloes. Furthermore, the most widely used criterion is also to determine the growth of animals by assessing their body weights. Body weight is significantly associated with the types of feed and ration offered.

According to Vahora et al. [79], improvements in the average daily weight gain, body length, height and heart girt in buffaloes fed with a basal diet were significantly associated with the incorporation of protein and fat supplements. Furthermore, offering supplementation at $0.6 \mathrm{~kg} / \mathrm{animal} /$ day to grazing buffaloes after weaning for a period of two years enabled the calves to reach an average of $578.38 \mathrm{~kg}$ body weight, with improved body condition scores [36]. Similarly, supplementing beef heifers with dietary energy supplements increased the average daily gain and utilization of energy from native forage which contained low-quality nutrients [93]. Sawyer et al. [94] also showed that supplementing with a low ratio of energy at $40 \mathrm{~g} /$ day of crude protein might potentially replace greater quantities ( $160 \mathrm{~g} /$ day of crude protein) while still maintaining rumen function. However, animals grazing on low-quality dormant range and fed with a supplementation had no change in body weight during pregnancy, breeding and longevity compared to those feds grazing without supplement or a lower rumen undegradable plant-based protein supplement [95]. However, adding supplemental fat in the ration at a rate of $5-7 \%$ dry matter (DM) resulted in an improved lamb weight at 15\% to 20\% [96]. Ngidi et al. [97] reported that the apparent digestibility of fat increased, whereas true digestibility lessened when fat was added at up to $8 \%$ of diet DM. Meanwhile, Kumar and Thakur [98] concluded that supplementation of bypass fat at $2.5 \%$ to $4 \%$ of dry matter intake increased average daily gain and feed conversion ratio in buffalo calves and improved the growth performance without an adverse effect on nutrient utilization. It was concluded that addition of $2 \%$ to $4 \%$ of fat potentially stimulated feed intake and increased ruminant's digestibility energy intake [99]. 


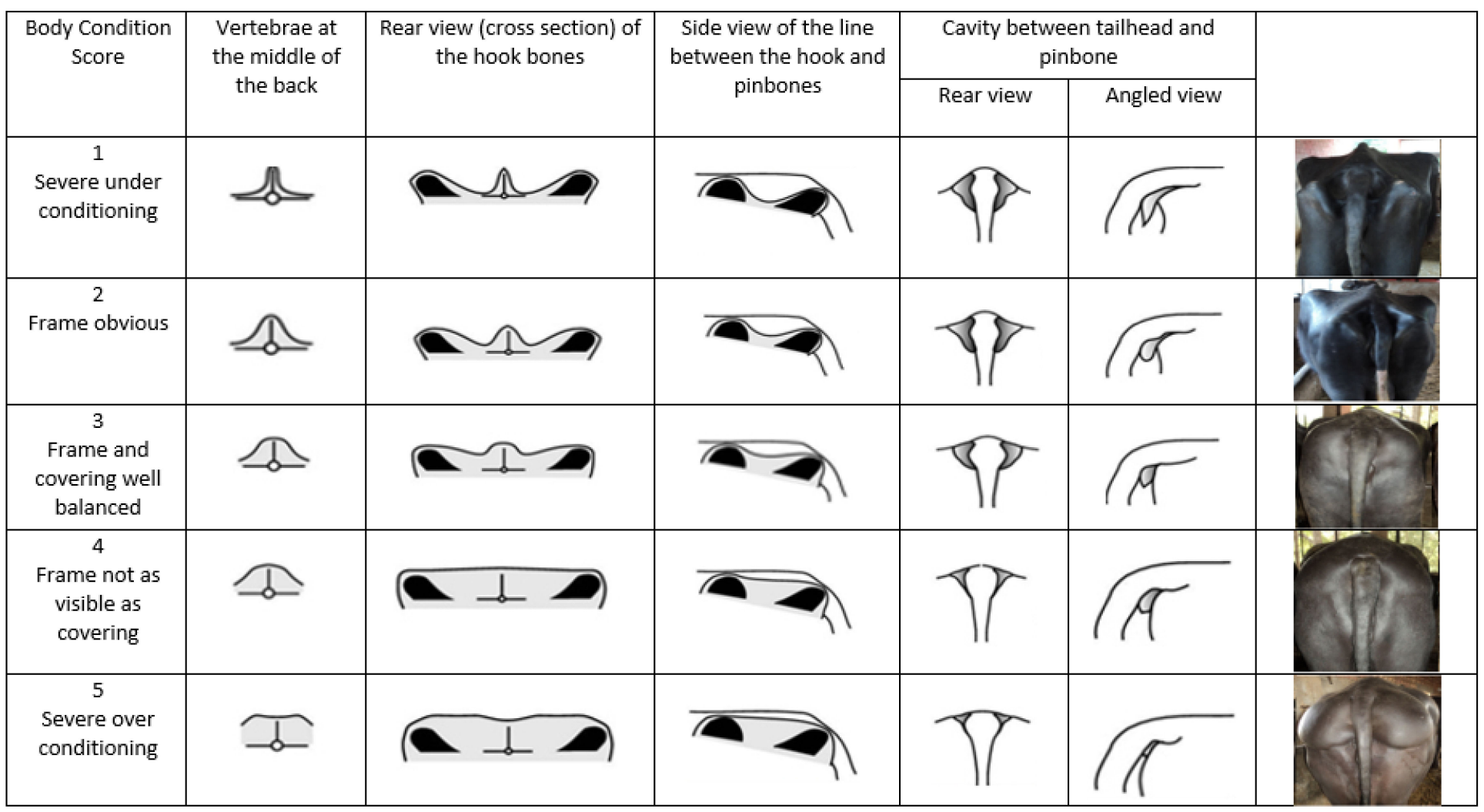

Figure 4. Body condition scoring chart for buffalo in a scale using 1.0 increments. Reprinted with permission from ref. [87]. Copyright 2017 Singh et al. 


\subsection{Serum Biochemistry and Hormone Profiles}

The main function of blood in the body is to maintain the physiological equilibrium, but many physiological conditions may alter this equilibrium [100]. Blood contains a myriad of constituents that provide a valuable medium for clinical investigations and nutritional evaluations of an organism [101]. Serum biochemicals can be affected by age, nutrition, physiological status, sex, genetics, environmental factors and stresses, such as diseases and transportation [102]. The consequences of these variables can be measured by evaluating the physiological responses, since it is known that environmental and nutritional factors predispose animals to the occurrence of disease and decrease animal productivity. Such deviations from normal alter animal body constituents, especially the body fluids, thus health risk conditions can be well-understood by evaluating blood components. Disease incidence and malnutrition could be diagnosed by analyzing the deviations of the various hematological and serum biochemical parameters from the normal reference values [103]. In fact, these values are used to compare and interpret the metabolic state or condition of animals as a reference point [104].

In the ruminant industry, analysis of blood metabolic profiles for assessing the nutritional and health status of goats, cows and buffaloes are not widely used [105], although the health and nutritional status of animals are important. However, the conventional and common practices used to evaluate the nutritional status of animals include the body condition scoring and the gain of body weights. Therefore, the use of blood metabolites is less common in assessing nutritional status of ruminants, especially among smallholder farmers in developing countries [106,107]. Needless to say, there are some blood metabolites that are related to the nutritional status of ruminants, and they reflect the animal's response to nutrition. They include blood total protein, cholesterol, triglyceride, glucose and urea.

Blood metabolites could be used regularly, objectively and reliably to assess the nutritional status of animals. However, the use of blood metabolite analysis in field buffalo and cattle is rare, particularly in developing countries such as Southern Africa and India due to the high cost of analyzing the samples, lack of equipment and expertise [106,107]. Similarly, the use of blood metabolites is quite uncommon in the field of buffalo management. This is unfortunate since several factors, namely the animal physiological status, nutrition, breed, age and season, are found to affect the blood metabolites, and in combination with data from body condition scores and body weights, blood metabolite analysis increases the accuracy of assessing the nutritional and welfare states of the ruminant population [107]. The success of the blood metabolite profile test alone is limited because several non-dietary factors also influence the concentrations of blood metabolites, such as herd origin, lactation stage, milk yield and season of the year [108].

According to Campanile et al. [109], the buffalo heifers fed Brachiaria hay with concentrate (high-energy diet) showed similarities in non-esterified fatty acid and triglyceride levels when compared to the group fed a low-energy diet (without concentrate) ( 0.53 vs. $0.47 \mathrm{mmol} / \mathrm{L}, 17.1$ vs. $18.7 \mathrm{mg} / \mathrm{dL}$, respectively), but there were significant increments in glucose, total cholesterol and high-density lipoprotein $(90.5 \mathrm{vs} .73 .6 \mathrm{mg} / \mathrm{mL}$, 80.4 vs. $58.7 \mathrm{mg} / \mathrm{dL}, 64.0$ vs. $45.4 \mathrm{mg} / \mathrm{dL}$, respectively). Bertoni et al. [110] have revealed that buffaloes fed isonitrogenous diets with different energy contents showed constant blood urea content regardless of the different diets, while cattle with similar treatment showed a significant decrease in blood urea with increasing dietary energy. This indicated the decline in ammonia content in the rumen of cattle as a result of the limited ability to recycle blood urea into the rumen. On the other hand, blood urea nitrogen of buffaloes would be at optimum range following feeding with different energy content diets that ranged between 7.00 and $8.50 \mathrm{~g} / \mathrm{dL}$ [111]. Tiwari et al. [112] reported that the normal glucose levels in growing buffaloes and Holstein cattle were 51 to 64 and 74 to $76 \mathrm{mg} / \mathrm{dL}$ respectively, when provided concentrate and roughages at an equal ratio. Other studies reported that Murrah buffalo fed a basal diet with concentrate supplementation and a mixture of concentrate with bypass fat supplementation had no effect on the blood urea nitrogen (BUN) 
(49.30 vs. $50.41, \mathrm{mg} / \mathrm{L})$, total protein (7.57 vs. $7.75, \mathrm{~g} / \mathrm{dL})$, albumin (2.71 vs. $2.84, \mathrm{~g} / \mathrm{dL})$, globulin (4.86 vs. $4.91, \mathrm{~g} / \mathrm{dL}$ ) and cholesterol (106.27 vs. 106.36, mg/dL) levels [113]. However, the buffaloes that were fed with supplement bypass fat showed slightly increased high-density lipoprotein and calcium levels as compared to animals fed without the bypass fat (65.55 vs. $57.22 \mathrm{mg} / \mathrm{dL}$ and 7.03 vs. $5.70 \mathrm{mg} / \mathrm{dL}$, respectively) [113,114]. Nevertheless, the buffaloes that were supplemented with bypass fat showed a slight decrement of blood glucose, non-esterified fatty acid and low-density lipoprotein levels as compared to animals fed without the bypass fat $(63.50 \mathrm{vs} .65 .98 \mathrm{mg} / \mathrm{dL}, 0.66 \mathrm{vs} .0 .93 \mathrm{mmol} / \mathrm{L}$, 33.66 vs. $37.49 \mathrm{mg} / \mathrm{dL}$, respectively) [113].

Similarly, hormonal profiles can also be used to determine the health and nutritional status of ruminants. Animal growth is influenced by many hormones, blood metabolites and growth factors acting both in an endocrine and an autocrine manner and requires the coordinated actions of several hormones, such as growth hormone (GH) and insulinlike growth factor-I (IGF-I) [115]. The somatropic axis is the important hormonal system for growth development of animals. It consists of GH, IGF-I, carrier proteins and receptors [116]. The hormones of GH and IGF-I have both independent characteristic and combined impacts on ruminant metabolism and production. The growth hormone is synthesized in the pituitary gland and acts directly on the liver and adipose tissue to regulate gluconeogenesis, protein synthesis, lipogenesis, lipolysis and insulin secretion by binding to the growth hormone receptor (GHR) [117-119]. On the other hand, IGF-I is a critical somatomedin that is synthesized in the liver. It plays an important role in some physiological processes, contributes to improved feed conversion rate and increases protein synthesis [120]. The IGF-I binds to insulin-like growth factor binding protein-3 (IGFBP-3) to influence the growth, development and reproduction in animals [121]. Meanwhile, the existence of the axis between GH and IGF-I has played a vital role in the regulation of metabolism. GHR combines with GH to stimulate a series of metabolic activities by producing IGF-I in the target tissues, especially in the liver [122,123].

In some cases, nutritional factors are critical regulators of IGFs [124]. Deficiency in either energy or protein intake significantly decreases the IGF-I levels [124]. Similarly, Clemmons et al. [125] reported that low energy in the diet caused the IGF-I level to decrease 4-fold. In fact, limiting the energy in the diet increases the GH levels and reduces the IGF-I secretion [126,127]. Meanwhile, over-consumption increases the IGF-I, although excess calories are not nearly as strong a stimulus as nutritional restriction [128]. A short-term feeding study on protein deprivation revealed a potent and independent role of protein on the IGF-I levels. Deficiency of essential amino acids has a severe depressing effect on the IGF-I levels [124]. However, a high-carbohydrate diet increases the IGF-I levels relative to a high-fat diet, possibly by maintaining hepatic sensitivity to GH [129]. Several researchers have recorded that yaks and buffaloes have evolved and developed complex strategies to respond to the deficiencies of nutrition and hypoxia stress [130-132].

According to Campanile et al. [109], buffalo heifers fed with Brachiaria hay and supplemented with concentrate (high-energy diet) showed increases in GH and IGF-1 levels compared to buffalo fed with a basal diet without concentrate (low-energy diet) (6.3 vs. $5.6 \mathrm{pg} / \mathrm{mL}, 95.5$ vs. $79.1 \mathrm{ng} / \mathrm{mL}$, respectively). Other studies also revealed that Murrah buffalo increased IGF-1 and remain constant in GH levels when fed a diet supplemented with a mixture of concentrate with bypass fat when compared to being fed with a diet supplemented solely by concentrate (119.10 vs. $116.24 \mathrm{ng} / \mathrm{mL}, 4.91 \mathrm{vs} .4 .93 \mathrm{ng} / \mathrm{mL}$, respectively) $[113,133]$. Even though a few studies have shown the effects of dietary fat and protein supplements on the serum biochemistry profiles as well as the hormonal profiles in the blood, unfortunately, limited work has been performed on the comparison of blood and hormonal profiles between buffalo breeds.

\subsection{Rumen Fermentation Pattern}

Rumen digestion is fundamentally a fermentation process within the rumen by various types of bacteria, protozoa and fungi [134]. These microbes are responsible for the 
breakdown of feed and water intake into volatile fatty acids (VFA), gases (i.e., methane, carbon dioxide) and microbial proteins that are useful for the animal. For the rumen microbes to function properly, the rumen environment parameters including $\mathrm{pH}$, temperature and moisture must be maintained [134]. Therefore, the outcome of rumen fermentation depends on adequate nutrition with respect to composition and quality of feedstuffs, which is reflected in the voluntary intake and digestibility of ruminants [135].

Buffaloes are like cattle which utilize micro-organisms in the rumen to digest the feed. It has been reported that many farms until today fed their buffaloes using cow requirements as a reference point [136]. This might be due to the similarities in rumen fermentation characteristics between buffalo and cow. According to Smith et al. [137], both animals have similarities in heat tolerance, milk composition and ability to utilize highly fibrous feed $[138,139]$. Nevertheless, studies also revealed that buffaloes indeed have higher forage digestibility due to higher populations of cellulolytic bacteria, total fungi and lower protozoa numbers in their rumen, as compared to cattle rumen $[140,141]$. Therefore, it is important to understand the rumen fermentation and the ruminal microbial differences between buffaloes and cows when formulating a feeding regime for them [138].

Changes in diet, from forage to high-protein diet, can affect the fermentation process of ruminants such as cattle and buffalo. The increase in dietary crude protein $(\mathrm{CP})$ leads to increased concentration of total rumen volatile fatty acid (VFA), which is consistent with the improved degradability following increased bacterial populations and microbial enzyme activities [142,143]. A study by Kang et al. [144] reported that Swamp buffalo fed with a high concentrate $(160 \mathrm{~g} / \mathrm{kg} \mathrm{DM})$ supplement ratio had constant ruminal $\mathrm{pH}$ (average 6.59 to 6.61) and temperature (average 39.1 to $39.3^{\circ} \mathrm{C}$ ), but had increased values of ammonia, total VFA, propionic acid, butyric acid of $9.8 \mathrm{vs} .13 .8 \mathrm{mg} / \mathrm{dL}, 20.1 \mathrm{vs} .26 .2 \mathrm{~mol} / 100 \mathrm{~mol}$ and 10.7 vs. $12.3 \mathrm{~mol} / 100$ respectively, when compared to animals fed with low concentrate (120 g/kg DM).

Carbohydrate in the diet is mainly characterized by the proportion of non-structural (NSC) and structural carbohydrate $[145,146]$. In the rumen, the NSC are initially utilized by the rumen microbes and are degraded quickly to produce volatile fatty acids [147]. Sutton et al. [148] confirmed that high NSC in the concentrate diet resulted in higher propionate concentration, while McCarthy et al. [149] also concluded that increasing the content of ruminal fermentable starch enhanced the total volatile fatty acid (TVFA) concentration. In fact, decreased ruminal $\mathrm{pH}$ was also reported following high intake levels of dietary crude protein, and this was attributed to the increased ruminal total VFA output $[150,151]$. Ruminal ammonia-nitrogen $\left(\mathrm{NH}_{3}-\mathrm{N}\right)$ is primarily derived from ruminal degradable proteins and is used for the synthesis of microbial protein [152,153]. An increase in ruminal $\mathrm{NH}_{3}-\mathrm{N}$ content occurs following an increase in dietary $\mathrm{CP}$ levels [152] and is largely attributed to the increased ruminal CP degradability [154]. However, an increase in dietary concentrate or carbohydrate is not a successful strategy to mitigate either the enteric methane production or ammonia emission from the manure. Therefore, incorporating supplemented concentrate with bypass fat has the potential of reducing the methane and ammonia productions.

Unfortunately, a study by Budi et al. [155] found that the increased level of bypass fat significantly reduced the in vitro dry matter degradability, but the levels of TVFA and ammonia nitrogen remained constant, while Naik et al. [156] revealed that following in vitro fermentation, the levels of TVFA and ammonia nitrogen were much higher in animals fed with a diet with concentrate and bypass fat compared to those fed without the supplement. Saijpaul et al. [157] recommended that the high level of bypass fat supplementation could substitute up to $40 \%$ of natural fat in a concentrate mixture $(6 \%$ natural fat) contained in total mixed rations (50:50 roughage to concentrate) with no changes in in vitro fermentation parameters of TVFA, total nitrogen and ammonia. Other studies also reported that supplementation of bypass fat between $5 \%$ and $15 \%$ in buffalo diet had no adverse effect on the in vivo rumen fermentation characteristics such as $\mathrm{pH}$, $\mathrm{NH}_{3}-\mathrm{N}$ and VFA levels [158-160]. The specific ingredient of dietary buffer in calcium salt 
bypass fat functioned to maintain ruminal $\mathrm{pH}$ and to minimize the rate of dissociation of calcium salts in the rumen [82], thus the rate of biohydrogenation was potentially reduced. In summary, supplementation of solely concentrate in a basal diet could affect the buffalo rumen fermentation characteristics but no adverse effects were found on the reported parameters when buffaloes fed given the mixture of concentrate and bypass fat in the diet.

\subsection{Rumen Microbial Populations}

It is also known that the feed and feeding regime in ruminants may also significantly affect the ruminal microbial community. Indeed, it has been demonstrated that the composition of the rumen bacterial population significantly correlated with feed efficiency [161,162]. A study showed that changes in the structure of the ruminal microbial population potentially promoted feed efficiency, intake and the average daily gain of ruminants [163]. The microorganisms also often provided the host ruminant with nutrients to produce energy [164]. Thus, increased ruminant production could be achieved by using proper feeding formulation and management that were able to manipulate the ruminal microbes and ecosystem. For example, a proper ratio of supplemented feed in the diet that provided adequate energy and protein, allowed for an optimal ruminal fermentation process that maximized production efficiency while decreasing energy loss such as methane that polluted the environment [165]. Indeed, there were also reports on the effects of dietary changes involving protein and energy on rumen microbial population and the rumen environment in ruminants [166].

The effects of dietary energy and protein supplementation on the rumen microbial population have been studied extensively in sheep, goat and cow, but less so in buffaloes. Indeed, a study by Dahllöf et al. [167] has reported that dietary modifications in cattle feeding have major effects on the communities of rumen bacteria. Faniyi et al. [168] also stated that a shift in the ruminant diet from forage-based to a high-concentrate diet resulted in significant alterations of the ruminal environment and rumen bacterial population structure. Indeed, various studies also showed that there were clear changes in the structure of the rumen bacterial population as the dietary forage to concentrate ratio gradually increased from 80:20 to 60:40 or even to 20:80, with increases in Proteobacteria and decreases in Firmicutes [168-172]. The increased abundance of Proteobacteria during high-concentrate diets was suggestive of an increased need for bacterial species that could metabolize the newly available fermentable carbohydrates [169], thus favoring the growth of amylolytic and other starch-digesting bacterial species and reducing the number of cellulolytic bacteria. This suggested that when animals were shifted from a forage diet to a high-concentrate diet, the microbial diversity in terms of the different species numbers remained but the composition or the species makeup changed drastically in order to adapt to the new rumen environment.

Fibrobacter succinogenes, a fibrolytic bacterium that digests fiber, was reported to be gradually decreased as animals were adapted to a high-concentrate diet, and their numbers were 40-fold lower than in those animals fed on hay [169]. A study by Tajima et al. [173] reported a 20-fold decrease in the Fibrobacter population size by day 3 and a 57 -fold decrease by day 28 in animals on high-concentrate diets. The population of Butyrivibrio fibrisolvens, another fibrolytic bacterium with high affinity toward maltose and sucrose, also declined 20-fold during adaptation to a high-concentrate diet [172]. Due to the ability of this species to use both cellulose and starch, the Butyrivibrio fibrisolvens population showed a slight decrease in the rumen environment [169]. However, the drop in the population of Butyrivibrio fibrisolvens during a diet with a high proportion of concentrate (30:80) might be because of $\mathrm{pH}$ changes due to the increased number of fermentable substrates present within the rumen. This was consistent with the findings of a recent study which showed that the population of Butyrivibrio fibrisolvens increased in high-fiber diets and decreased in high-energy diets $[174,175]$.

Changes in bacterial populations with increasing dietary crude protein were attributed to the increased ruminal amino acids, peptides, branched chain VFA and $\mathrm{NH}_{3}-\mathrm{N}[176,177]$. 
Moreover, it was reported by Wang et al. [178] that increased dietary crude protein would enhance ruminal microbial growth, particularly of the bacterial populations in the rumen fluid that consisted of Ruminococcus albus, Ruminococcus flavefaciens, Butyrivibrio fibrisolvens, Prevotella ruminicola, Fibrobacter succinogenes and Ruminobacter amylophilus. In general, the improved microbial enzyme activity has a significant relationship with the increase of the bacterial populations in the rumen [143]. In particular the activities of cellobiase, xylanase, pectinase, carboxymethyl-cellulase, pectinase, protease and $\alpha$-amylase increased following an increase in dietary protein. However, another researcher showed that lambs fed with a diet containing crude protein levels from 111.7 to $143.6 \mathrm{~g} / \mathrm{kg}$ DM did not show any effect on the rumen microbial population of $R$. albus, $R$. flavefaciens and F. succinogenes [179]. These contradictory findings might be due to the differences in the animals studied and the dietary composition [151,179].

\subsection{Qualities of Carcass and Buffalo Meat and Their Implications on Human Health}

Nutrition is a dominant component of livestock production systems that influences several aspects of meat quality. Consumer demands on meat quality have motivated the meat producers to focus on the nutritional aspects of livestock rearing since carcass and meat qualities are affected by the amount and type of nutrient intake. These include dressing yield, meat to bone ratio, protein to fat ratio, fatty acid composition, caloric value, color, physicochemical and processing properties, shelf life and sensory attributes [180].

Dressing percentage is one of the important parameters that reflects the potential meat yield from an animal. Usually, the weight of hot carcass is used to compute the dressing percentage. When the weight of cold carcass is used, the dressing percentage is less due to the chilling shrinkage that ranges between $3 \%$ and $4.5 \%$ of the initial weight of the hot carcass for buffaloes at the age of 6 months up to 4 years [181]. Other than chilling, a feeding diet with supplementation might inconsistently influence the carcass quality. Anjaneyulu et al. [182] reported that supplemented dietary protein did not affect the carcass composition of male buffalo. However, the dressing percentages and yields of the lean meat were higher when buffaloes were fed a high-energy diet compared to those fed a low-concentrate diet [112]. Nevertheless, based on the current information, it was concluded that feed supplementation had little effect on the carcass quality of buffaloes.

Meat quality is a major factor that is used for marketing the product [183]. The meat quality is evaluated through physical, biochemical, histological and sensory analyses. The nutritional composition and $\mathrm{pH}$ of meat are parts of the biochemical analyses used in assessing the meat quality, which contribute to the edibility or the desirability of the product [184]. Three crucial factors can affect the quality and composition of the meat produced [185]. They are: (1) the feedstuffs and proportion of the diet used for feeding the animal, (2) types of diet, supplement, breed or genetic cross of the animal and (3) the age at which the animal is slaughtered. Meanwhile, diet has been shown to be one of the most important environmental factors that influences the carcass yield, meat cutability and quality $[186,187]$. The effects of feeding on meat quality are generally studied in terms of the content and composition of the lean and fat tissues, and the subsequent effects on the nutrient content of protein, fat, energy and moisture content.

In particular, the total fatty acid content and the types of fatty acid found in meat have major influences on the meat quality and acceptability of the meat by consumers [187]. Feeding a high-energy diet potentially affects the rate of conditioning and consequently, the carcass composition, conformation, meat yield and meat and fat quality [188].

Carabeef, also known as buffalo meat, is considered to be a highly nutritious and valuable food. It is a source of high biological value of protein, omega 3 and omega 6 fatty acids and low in fat and cholesterol levels [189]. However, different nutrient contents of buffalo meat have been reported due to different feeding regimes [190]. Lambertz et al. [191] proposed a concentrate supplementation at the rate of approximately $1.5 \%$ of body weight to enhance the carcass characteristics of Swamp buffaloes via expressing superior dressing percentage, better muscling and redder meat, with higher contents of protein and fat. 
Furthermore, addition of a fat supplement enables facilitated absorption of liposoluble nutrients, making it possible to modify the meat fat composition according to consumers demand [192]. Moreover, the high energy levels allow the increase of pulp proportion in the diet of fattening animals, which act as precursors of the fatty acid responsible for the lack of consistency of fat from carcasses [193].

\section{Conclusions}

From the available literature, it can be summarized that supplementation of concentrate and bypass fat in a potential buffalo diet is very important to overcome the problem of negative energy balance without adversely affecting the dry matter intake, rumen fermentation, blood metabolites and rumen microbial populations. Supplementation of concentrate and bypass fat provides additional benefits due to improved ruminant body weight, body condition score and the economics of the ruminant industry. Further research is necessary to find out the effects of supplementation with concentrate and bypass fat on growing buffaloes fed with various types of basal rations at different productive levels.

Author Contributions: H.A.H. conceived the manuscript purpose and design and critically revised the manuscript. A.F.M.A. wrote the initial version of the manuscript and revised according to H.A.H.'s suggestions. All authors (H.A., N.M.N., Y.-M.G., M.Z.-S., M.Z.A.B., A.S., P.A. and A.J.) read and approved the final manuscript. All authors have read and agreed to the published version of the manuscript.

Funding: The whole research work and manuscript writing were fully funded by the Ministry of Science, Technology, and Innovation (MOSTI), Malaysia, under the FLAGSHIP Research Grant Scheme (Project Title: Enhancing the Productivity of Farm Buffalo (Bubalus bubalis) Through Modification of Rearing Practices; Reference number: FP05514B0020-2(DSTIN)/6300858). Amirul Faiz M. A. was a recipient of a Graduate Research Fellowship from the Universiti Putra Malaysia.

Institutional Review Board Statement: Not applicable.

Data Availability Statement: Not applicable.

Acknowledgments: The authors would like to thank the staff members of Jabatan Penternakan Haiwan dan Perusahaan Ternak (JPHPT) and the Buffalo Breeding and Research Centre, Telupid Sabah, as well as all postgraduate students and staff from Nutrition Lab, Faculty of Veterinary Medicine, Universiti Putra Malaysia, for their assistance in this study. This study was financially supported by the Flagship Research grant ABI/FS/2016/01 of the Ministry of Science, Technology, and Innovation, Malaysia, and Ministry of Higher Education Malaysia through Higher Institution Centres of Excellence (HiCoE) and Universiti Putra Malaysia.

Conflicts of Interest: The authors declare that they have no competing interests.

$\begin{array}{ll}\text { Abbreviations } \\ \text { CP } & \text { Crude protein } \\ \text { RUP } & \text { Rumen undegradable protein } \\ \mathrm{kg} & \text { Kilogram } \\ \mathrm{g} & \text { Gram } \\ \mathrm{mg} & \text { milligram } \\ \text { ADG } & \text { Average daily gain } \\ \text { TVFA } & \text { Total volatile fatty acid } \\ \text { DM } & \text { Dry matter } \\ \text { BW } & \text { Body weight } \\ \text { BCS } & \text { Body condition score } \\ \text { NEFA } & \text { Non-esterified fatty acid } \\ \text { dl } & \text { Deciliter } \\ \text { GH } & \text { Growth hormone } \\ \text { IGF-1 } & \text { Insulin-like growth factor- } 1 \\ \text { GHR } & \text { Growth hormone receptor } \\ \text { BUN } & \text { Blood urea nitrogen }\end{array}$




\section{References}

1. Işik, M.; Gül, M. Economic and social structures of water buffalo farming in Muş province of Turkey. Rev. Bras. Zootec. 2016, 45, 400-408. [CrossRef]

2. Cockrill, W.R. The working buffalo. In The Husbandry and Health of the Domestic Buffalo; Food and Agricultural Organization of the United Nations: Rome, Italy, 1974.

3. Scherf, B.D. World Watch List for Domestic Animal Diversity, 3rd ed.; Food and Agriculture Organization (FAO): Rome, Italy, 2000.

4. Kumar, S.; Nagarajan, M.; Sandhu, J.S.; Kumar, N.; Behl, V.; Nishanth, G. Mitochondrial DNA analyses of Indian water buffalo support a distinct genetic origin of river and swamp buffalo. Anim. Genet. 2007, 38, 227-232. [CrossRef] [PubMed]

5. Andrabi, S.M.H. Applied andrology in water buffalo. Anim. Androl. Theor. Appl. 2014, 380-403. [CrossRef]

6. Shaari, N.A.L.; Jaoi-Edward, M.; Loo, S.S.; Salisi, M.S.; Yusoff, R.; Ab Ghani, N.I.; Saad, M.Z.; Ahmad, H. Karyotypic and mtDNA based characterization of Malaysian water buffalo. BMC Genet. 2019, 20, 1-6. [CrossRef]

7. McGrath, J.; Duval, S.M.; Tamassia, L.F.; Kindermann, M.; Stemmler, R.; de Gouvea, V.N.; Acedo, T.S.; Immig, I.; Williams, S.N.; Celi, P. Nutritional strategies in ruminants: A lifetime approach. Res. Veter. Sci. 2018, 116, 28-39. [CrossRef]

8. Henry, B.; Charmley, E.; Eckard, R.; Gaughan, J.B.; Hegarty, R. Livestock production in a changing climate: Adaptation and mitigation research in Australia. Crop. Pasture Sci. 2012, 63, 191-202. [CrossRef]

9. Martin, G.B.; Kadokawa, H. "Clean, green and ethical” animal production. Case study: Reproductive efficiency in small ruminants. J. Reprod. Develop. 2006, 52, 145-152. [CrossRef]

10. Triwitayakorn, K.; Moolmuang, B.; Sraphet, S.; Panyim, S.; Na-Chiangmai, A.; Smith, D.R. Analysis of genetic diversity of the Thai swamp buffalo (Bubalus bubalis) using cattle microsatellite DNA markers. Asian Australas. J. Anim. Sci. 2006, 19, 617-621. [CrossRef]

11. Zhang, Y.; Colli, L.; Barker, J.S.F. Asian water buffalo: Domestication, history and genetics. Anim. Genet. 2020, 51, 177-191. [CrossRef]

12. Tuyen, D.K.; Ly, N.V. The role of swamp buffalo in agricultural production of small farm holder. In Proceedings of the National Workshop on Swamp Buffalo Development, Hanoi, Vietnam, 17-18 December 2001; p. 17.

13. Iannuzzi, L. A genetic physical map in river buffalo (Bubalus bubalis, $2 \mathrm{n}=50$ ). Caryologia 1998, 51, 311-318. [CrossRef]

14. Colli, L.; Milanesi, M.; Vajana, E.; Iamartino, D.; Bomba, L.; Puglisi, F.; Cruz, L. New insights on water buffalo genomic diversity and post-domestication migration routes from medium density SNP chip data. Front. Genet. 2018, 9, 53. [CrossRef]

15. Barker, J.S.F.; Moore, S.S.; Hetzel, D.J.S.; Evans, D.; Byrne, K. Genetic diversity of Asian water buffalo (Bubalus bubalis): Microsatellite variation and a comparison with protein-coding loci. Anim. Genet. 1997, 28, 103-115. [CrossRef]

16. Thu, N.V. Exploring Approaches to Research in Animal Sciences in Vietnam; Australian Centre for International Agricultural Research (ACIAR): Bruce, Australia, 1995; Volume 68, p. 216.

17. Nanda, A.S.; Nakao, T. Role of buffalo in the socioeconomic development of rural Asia: Current status and future prospectus. Anim. Sci. J. 2003, 74, 443-455. [CrossRef]

18. Benjamin, B.R. Cross-breeding among buffaloes, an unexploited natural resource. In Buffalo Newsletter, Bulletin of the FAO Inter-Regional Cooperative Research Network on Buffalo for Europe-Near East; The International Buffalo Federation (IBF): Rome, Italy, 1996.

19. Lemcke, B. Water buffalo. In The New Rural Industries-A Handbook for Farmers and Investors; Hyde, K., Ed.; Rural Industries Research and Development Corporation: Sydney, Australia, 1997.

20. Borghese, A. Buffalo Production and Research. REU Technical Series; Food and Agriculture Organization of the United Nations: Rome, Italy, 2005; p. 67.

21. Mohd Azmi, A.M.; Abu Hassim, H.; Nor, N.M.; Ahmad, H.; Meng, G.; Abdullah, P.; Bakar, A.; Vera, J.; Deli, N.M.; Salleh, A.; et al. Comparative growth and economic performances between indigenous swamp and Murrah crossbred buffaloes in Malaysia. Animals 2021, 11, 957. [CrossRef]

22. Hamid, M.; Ahmed, S.; Rahman, M.; Hossain, K. Status of buffalo production in Bangladesh compared to SAARC countries. Asian J. Anim. Sci. 2016, 10, 313-329. [CrossRef]

23. Hamid, M.; Siddiky, M.; Rahman, M.; Hossain, K. Scopes and opportunities of buffalo farming in Bangladesh: A review. SAARC J. Agric. 2017, 14, 63-77. [CrossRef]

24. Prasad, R.M.V.; Laxmi, P.J. Studies on the temperament of Murrah buffaloes with various udder and teat shapes and its effect on milk yield. Buffalo Bull. 2014, 33, 170-176.

25. Moioli, B.; Georgoudis, A.; Napolitano, F.; Catillo, G.; Giubilei, E.; Ligda, C.; Hassanane, M. Genetic diversity between Italian, Greek and Egyptian buffalo populations. Livest. Prod. Sci. 2001, 70, 203-211. [CrossRef]

26. Borghese, A.; Mazzi, M. Buffalo population and strategies in the world. Buffalo Prod. Res. 2005, 67, 1-39.

27. Borghese, A. Development and perspective of buffalo and buffalo market in Europe and near East. Proceedings of 9th World Buffalo Congress, Buenos Aires, Argentina, 25-28 April 2010; pp. 20-31.

28. Wanapat, M. Potential uses of local feed resources for ruminants. Trop. Anim. Heal. Prod. 2008, 41, 1035-1049. [CrossRef]

29. Ly, L.V. Overview on buffalo development in Vietnam. In Proceedings of the Regional Workshop on Water Buffalo Development, Bangkok, Thailand, 8-10 February 2001.

30. Ariff, O.M.; Sharifah, N.Y.; Hafidz, A.W. Status of beef industry of Malaysia. Malays. J. Anim. Sci. 2015, $18,1-21$.

31. Saadullah, M. Buffalo production and constants in Bangladesh. J. Anim. Plant Sci. 2012, 22, 221-224. 
32. Nahar, T.N.; Alam, M.K.; Akhtar, S. Study the assessment of nutritional composition and bacterial load in buffalo milk in some selected areas of Bangladesh. In Proceeding of the Annual Research Review Workshop, Umuahia, Nigeria, 17-19 April 2012; p. 13.

33. Momin, M.M.; Khan, M.K.I.; Miazi, O.F. Performance traits of buffalo under extensive and semi-intensive Bathan system. Iran. J. Appl. Anim. Sci. 2016, 6, 823-831.

34. Afzal, M.; Anwar, M.; Mirza, M.; Andrabi, S. Comparison of growth rate of male buffalo calves under open grazing and stall feeding system. Pak. J. Nutr. 2009, 8, 187-188. [CrossRef]

35. Zamri-Saad, M.; Azhar, K.; Zuki, A.B.; Punimin, A.; Hassim, H.A. Enhancement of performance of farmed buffaloes pasture management and feed supplementation in Sabah, Malaysia. Pertanika J. Trop. Agric. Sci. 2017, 40, 553-564.

36. Alves, T.C.; Franzolin, R. Growth curve of buffalo grazing on a grass pasture. Rev. Bras. Zootec. 2015, 44, 321-326. [CrossRef]

37. Shamsuddin, M.; Bhuiyan, M.M.U.; Sikder, T.K.; Sugulle, A.H.; Chanda, P.K.; Alam, M.G.S.; Galloway, D. Constraints Limiting the Efficiency of Artificial Insemination of Cattle in Bangladesh; International Atomic Energy Agency: Vienna, Austria, 2001.

38. Sarkar, S.; Hossain, M.M.; Amin, M.R. Socio-economic status of buffalo farmers and the management practices of buffaloes in selected areas of Bagerhat district of Bangladesh. Bangladesh J. Anim. Sci. 2013, 42, 158-164. [CrossRef]

39. Amin, M.R.; Siddiki, M.A.; Kabir, A.K.M.A.; Faruque, M.O.; Khandaker, Z.H. Status of buffalo farmer and buffaloes at Subornochar upozila of Noakhali District. Progress. Agric. 2015, 26, 71-78. [CrossRef]

40. Bartocci, S.; Di Lella, T. Capacità di utilizzazione digestiva degli alimenti. Agric. Ricerca 1994, 153, 49-56.

41. Puppo, S.; Bartocci, S.; Terramoccia, S.; Grandoni, F.; Amici, A. Rumen microbial counts and in vivo digestibility in buffaloes and cattle given different diets. Anim. Sci. 2002, 75, 323-329. [CrossRef]

42. Terramoccia, S.; Bartocci, S.; Amici, A.; Martillotti, F. Protein and protein-free dry matter rumen degradability in buffalo, cattle and sheep fed diets with different forage to concentrate ratios. Livest. Prod. Sci. 2000, 65, 185-195. [CrossRef]

43. Manish, P. Nutritional Requirement of Lactating Buffaloes. Benision Media Article. 2018. Available online: http://benisonmedia. $\mathrm{com} /$ nutritional-requirement-of-lactating-buffaloes (accessed on 18 January 2021).

44. Sarwar, M.; Khan, M.A.; Nisa, M.; Bhatti, S.A.; Shahzad, M.A. Nutritional management for buffalo production. Asian Australas. J. Anim. Sci. 2009, 22, 1060-1068. [CrossRef]

45. Iqbal, Z.M.; Abdullah, M.; Javed, K.; Jabbar, M.A.; Ahmed, N.; Ditta, Y.A.; Mustafa, H.; Shahzad, F. Effect of varying levels of concentrate on growth performance and feed economics in Nili-Ravi buffalo heifer calves. Turk. J. Veter. Anim. Sci. 2017, 41, 775-780. [CrossRef]

46. Terramoccia, S.; Bartocci, S.; Borghese, A. Nutritional requirements in buffalo cows and heifers. In Buffalo Production and Research, FAO Inter-Regional Cooperative Research Network on Buffalo, REU Technical Series; Food and Agriculture Organization Of the United Nations: Rome, Italy, 2005; Volume 67, pp. 145-160.

47. Zicarelli, L. Can we consider buffalo a non precocious and hypofertile species? Ital. J. Anim. Sci. 2007, 6, 143-154. [CrossRef]

48. Paul, S.S.; Mandal, A.B.; Pathak, N.N. Feeding standards for lactating riverine buffaloes in tropical conditions. J. Dairy Res. 2002, 69, 173-180. [CrossRef]

49. Campanile, G. Nutrition and milk production in dairy buffalo. In Proceedings of the III Simposio de Búfalos de las Américas and 2nd Buffalo Symposium of the Europe and Americans, Medelin, Colombia, 6-8 September 2006; pp. 132-141.

50. Pathak, N.N. Comparison of feed intake, digestibility of nutrients and performance of cattle (B. indicus and B. indicus $\times$ B. taurus crosses) and buffaloes (swamp and Indian). In Coping with Feed Scarcity in Smallholder Livestock Systems in Developing Countries; Ayantunde, A.A., Fernandez-Rivera, S., McCrabb, G., Eds.; Animal Science UR: Wageningen, The Netherlands; University of Reading: Reading, UK; Science Institute of Technology: Zurich, Switzerland; International Livestock Research Institute: Nairobi, Kenya, 2005; pp. 209-233.

51. Hayashi, Y.; Shah, S.; Shah, S.K.; Kumagai, H. Dairy production and nutritional status of lactating buffalo and cattle in small-scale farms in Terai, Nepal. Livest. Res. Rural Dev. 2005, 17, 65-74.

52. Paul, S.S.; Lal, D. Nutrient Requirements of Buffaloes; Satish Serial Publishing House: Delhi, India, 2010; pp. 5-17.

53. National Research Council-NRC. Nutrient Requirements of Domestic Animals: Nutrient Requirements of Dairy Cattle, 7th ed.; National Academy of Sciences: Washington, DC, USA, 2001; p. 333.

54. Agricultural and Food Research Council-AFRC. Technical Committee Reports; Agricultural and Food Research Council-AFRC: London, UK, 1991.

55. Bülbül, T. Energy and nutrient requirements of buffaloes. Kocatepe Vet. Dergisi 2010, 3, 55-64.

56. Fiest, M. Basic Nutrition of Bison; Saskatchewan Agriculture and Food: Moose Jaw, SK, Canada, 1999.

57. Tripaldi, C. Buffalo milk quality. In Buffalo Production and Research, FAO Inter-Regional Cooperative Research Network on Buffalo; REU Technical Series; Food and Agriculture Organization Of the United Nations: Rome, Italy, 2005; Volume 67, pp. 173-183.

58. Perry, T.W.; Cullison, A.E.; Lowrey, R.S. Feeds and Feeding, 6th ed.; Pearson Education, Inc.: Upper Saddle River, NJ, USA, 2004.

59. Bartocci, S.; Terramoccia, S.; Puppo, S. New acquisitions on the digestive physiology of the Mediterranean buffalo. In Buffalo Production and Research; Reu Technical Series; Borghese, A., Ed.; Food and Agriculture Organization of the United Nations: Rome, Italy, 2005; Chapter VIII; Volume 67, pp. 161-172.

60. Paulino, M.F.; Detmann, E.; Valente, E.E.L.; Barros, L.V. Nutrition of grazing cattle. In Proceedings of the 4th Symposium on Strategic Management of Pasture; Universidade Federal de Viçosa: Viçosa, Brazil, 2008; pp. 131-169. 
61. Figueiras, J.F.; Detmann, E.; Franco, M.O.; Batista, E.D.; Reis, W.L.S.; Paulino, M.F.; Filho, S.C.V. Effects of supplements with different protein contents on nutritional performance of grazing cattle during the rainy season. Asian Australas. J. Anim. Sci. 2016, 29, 1710-1718. [CrossRef]

62. Sabia, E.; Napolitano, F.; Claps, S.; Braghieri, A.; Piazzolla, N.; Pacelli, C. Feeding, nutrition and sustainability in dairy en-terprises: The case of Mediterranean buffaloes (Bubalus bubalis). In The Sustainability of Agro-Food and Natural Resource Systems in the Mediterranean Basin; Springer: Cham, Switzerland, 2015; pp. 57-64.

63. Detmann, E.; Valente, É.E.; Batista, E.D.; Huhtanen, P. An evaluation of the performance and efficiency of nitrogen utilization in cattle fed tropical grass pastures with supplementation. Livest. Sci. 2014, 162, 141-153. [CrossRef]

64. Sahoo, A.; Elangovan, A.V.; Mehra, U.R.; Singh, U.B. Catalytic supplementation of urea-molasses on nutritional performance of male buffalo (Bubalus bubalis) calves. Asian Australas. J. Anim. Sci. 2004, 17, 621-628. [CrossRef]

65. Wynn, P.C.; Warriach, H.M.; Morgan, A.; McGill, D.M.; Hanif, S.; Sarwar, M.; Iqbal, A.; Sheehy, P.A.; Bush, R.D. Perinatal nutrition of the calf and its consequences for lifelong productivity. Asian Australas. J. Anim. Sci. 2009, 22, 756-764. [CrossRef]

66. Lazzarini, I.; Detmann, E.; Valadares Filho, S.D.C.; Paulino, M.F.; Batista, E.D.; de Almeida Rufino, L.M.; Dos Reis, W.L.S.; de Oliveira Franco, M. Nutritional performance of cattle grazing during rainy season with nitrogen and starch supplementation. Asian Australas. J. Anim. Sci. 2015, 29, 1120-1128. [CrossRef] [PubMed]

67. Costa, V.A.C.; Detmann, E.; Paulino, M.F.; Valadares Filho, S.D.C.; Henriques, L.T.; Carvalho, I.P.C.D. Total and partial digestibility and nitrogen balance in grazing cattle supplemented with non-protein and, or true protein nitrogen during the rainy season. Rev. Bras. Zootec. 2011, 40, 2815-2826. [CrossRef]

68. Raleigh, R.J.; Lesperance, A.L. Range cattle nutrition. In Digestive Physiology and Nutrition of Ruminants; Church, D.C., Ed.; Oregon State University Bookstores: Corvallis, OR, USA, 1972.

69. Loerch, S.C. Effects of feeding growing cattle high-concentrate diets at a restricted intake on feedlot performance. J. Anim. Sci. 1990, 68, 3086-3095. [CrossRef]

70. Del Curto, T.R.C.; Cochran, D.L.; Harmon, A.A.; Beharka, K.A.; Jacques, G.T.; Vanzant, E.S. Supplementation of dormant tallgrass-prairie for age: I. Influence of varying supplemental protein and (or) energy levels on forage utilization characteristics of beef steers in confinement. J. Anim. Sci. 1990, 68, 515-522. [CrossRef]

71. Ba, N.X.; Van, N.H.; Ngoan, L.D.; Leddin, C.M.; Doyle, P.T. Effects of amount of concentrate supplement on forage intake, diet digestibility and live weight gain in yellow cattle in Vietnam. Asian Australas. J. Anim. Sci. 2008, 21, 1736-1744. [CrossRef]

72. Agle, M.; Hristov, A.N.; Zaman, S.; Schneider, C.; Ndegwa, P.M.; Vaddella, V.K. Effect of dietary concentrate on rumen fermentation, digestibility, and nitrogen losses in dairy cows. J. Dairy Sci. 2010, 93, 4211-4222. [CrossRef]

73. Liu, H.; Xu, T.; Xu, S.; Ma, L.; Han, X.; Wang, X.; Zhang, X.; Hu, L.; Zhao, N.; Chen, Y.; et al. Effect of dietary concentrate to forage ratio on growth performance, rumen fermentation and bacterial diversity of Tibetan sheep under barn feeding on the Qinghai-Tibetan plateau. Peer J. 2019, 7, e7462. [CrossRef]

74. Shahudin, M.S.; Ghani, A.A.A.; Zamri-Saad, M.; Zuki, A.B.; Abdullah, F.F.J.; Wahid, H.; Hassim, H.A. The necessity of a herd health management programme for dairy goat farms in Malaysia. Pertanika J. Trop. Agric. Sci. 2018, 41, 1-18.

75. Suharti, S.; Astuti, D.A.; Wina, E.; Toharmat, T. Rumen microbial population in the in vitro fermentation of different ratios of forage and concentrate in the presence of whole lerak (Sapindus rarak) fruit extract. Asian Australas. J. Anim. Sci. 2011, 24, 1086-1091. [CrossRef]

76. Van Dung, D.; Shang, W.; Yao, W. Effect of crude protein levels in concentrate and concentrate levels in diet on in vitro fermentation. Asian Australas. J. Anim. Sci. 2014, 27, 797. [CrossRef]

77. Krause, K.M.; Oetzel, G. Understanding and preventing subacute ruminal acidosis in dairy herds: A review. Anim. Feed. Sci. Technol. 2006, 126, 215-236. [CrossRef]

78. Tahir, M.; Hetta, M.; Larsen, M.; Lund, P.; Huhtanen, P. In vitro estimations of the rate and extent of ruminal digestion of starch-rich feed fractions compared to in vivo data. Anim. Feed. Sci. Technol. 2013, 179, 36-45. [CrossRef]

79. Vahora, S.; Parnerkar, S.; Kore, K. Effect of feeding bypass nutrients to growing buffalo heifers under field conditions. Livest. Res. Rural Dev. 2012, 24, 39.

80. Yadav, C.M.; Chaudhary, J.L. Effect of feeding protected protein on growth performance and physiological reaction in crossbred heifers. Indian J. Anim. Nutr. 2010, 27, 401-407.

81. Behan, A.A.; Loh, T.C.; Fakurazi, S.; Kaka, A.; Samsudin, A.A.; Kaka, U. Effects of supplementation of rumen protected fats on rumen ecology and digestibility of nutrients in sheep. Animals 2019, 9, 400. [CrossRef]

82. Naik, P.K.; Saijpaul, S.; Kaur, K. Effect of supplementation of indigenously prepared rumen protected fat on rumen fermentation in buffaloes. Indian J. Anim. Sci. 2010, 80, 902.

83. Naik, P.K. Bypass fat in dairy ration-A review. Anim. Nutr. Feed Technol. 2013, 13, 147-163.

84. Bharadwaj, A.; Sengupta, B.P.; Sethi, R.K. Effect of feeding protected and unprotected protein on nutrients intake and reproductive performance of lactating buffaloes. Indian J. Anim. Sci. 2000, 70, 428-430.

85. Chatterjee, A.; Walli, T.K. Effect of feeding formaldehyde treated mustard cake as bypass protein on milk yield and milk composition of Murrah buffaloes. Indian J. Dairy Sci. 2003, 56, 299-306.

86. Park, B.K.; Choi, N.-J.; Kim, H.C.; Kim, T.I.; Cho, Y.M.; Oh, Y.K.; Im, S.K.; Kim, Y.J.; Chang, J.S.; Hwang, I.H.; et al. Effects of amino acid-enriched ruminally protected fatty acids on plasma metabolites, growth performance and carcass characteristics of Hanwoo steers. Asian Australas. J. Anim. Sci. 2010, 23, 1013-1021. [CrossRef] 
87. Singh, R.; Randhawa, S.S.; Randhawa, C.S. Body condition scoring by visual and digital methods and its correlation with ultrasonographic back fat thickness in transition buffaloes. Buffalo Bull. 2017, 36, 169-182.

88. Moran, J.B. Growth and development of buffaloes. In Buffalo Production; Tulloh, N.M., Holmes, J.H.G., Eds.; Elsevier: Amsterdam, NY, USA, 1992; pp. 191-221.

89. Garnsworthy, P.C. The effect of energy reserves at calving on performance of dairy cows. In Nutrition and Lactation in the Dairy Cow; Garnsworthy, P.C., Ed.; Butterwooths: London, UK, 1988.

90. Mirza, R.H.; Javed, K.; Abdullah, M.; Pasha, T.N. Genetic and non-genetic factors affecting body condition score in Nili Ravi buffaloes and its correlation with milk yield. J. Anim. Plant Sci. 2013, 23, 1486-1490.

91. FAO, Food and Agriculture Organization of the United Nation. FAO Food and Nutrition Paper; FAO: Rome, Italy, 2004; pp. 22661-23667.

92. Anitha, A.; Rao, K.S.; Suresh, J.; Moorthy, P.S.; Reddy, Y.K. A body condition score (BCS) system in Murrah buffaloes. Buffalo Bull. 2011, 30, 79-96.

93. Lalman, D.L.; Petersen, M.K.; Ansotegui, R.P.; Tess, M.W.; Clark, C.K.; Wiley, J.S. The effects of ruminally undegradable protein, propionic acid, and monensin on puberty and pregnancy in beef heifers. J. Anim. Sci. 1993, 71, 2843-2852. [CrossRef] [PubMed]

94. Sawyer, J.E.; Mulliniks, J.T.; Waterman, R.C.; Petersen, M.K. Influence of protein type and level on nitrogen and forage use in cows consuming low-quality forage. J. Anim. Sci. 2012, 90, 2324-2330. [CrossRef] [PubMed]

95. Mulliniks, J.T.; Hawkins, D.E.; Kane, K.K.; Cox, S.H.; Torell, L.A.; Scholljegerdes, E.J.; Petersen, M.K. Metabolizable protein supply while grazing dormant winter forage during heifer development alters pregnancy and subsequent in-herd retention rate. J. Anim. Sci. 2013, 91, 1409-1416. [CrossRef]

96. Delmotte, C.; Rondia, P.; Raes, K.; Dehareng, F.; Decruyenaere, V. Omega 3 and CLA naturally enhanced levels of animal products: Effects of grass and linseed supplementation on the fatty acid composition of lamb meat and sheep milk. In Proceedings of the 11th Seminar of the FAO-CIHEAM Sub-Network on Sheep and Goat Nutrition Advanced Nutrition and Feeding Strategies to Improve Sheep and Goat Production, Catania, Italy, 8-10 September 2005; Volume 24.

97. Ngidi, M.E.; Loerch, S.C.; Fluharty, F.L.; Palmquist, D.L. Effects of calcium soaps of long-chain fatty acids on feedlot performance, carcass characteristics and ruminal metabolism of steers. J. Anim. Sci. 1990, 68, 2555-2565. [CrossRef]

98. Kumar, B.; Thakur, S.S. Effect of supplementing bypass fat on the performance of buffalo calves. Indian J. Anim. Nutr. 2007, 24, 233-236.

99. Mierlita, D.; Padeanu, I.; Daraban, S.; Lup, F.; Maerescu, C.; Chereji, I. Effect of dietary supplementation with different types of protected fat on bioproductive performances and quality of carcass in sheeps. In Analele Universitătii din Oradea, Fascicula: Ecotoxicologie, Zootehnie și Tehnologii de Industrie Alimentară; Editura Universităţii din Oradea: Oradea, Romania, 2010; pp. 607-614.

100. Ahmad, I.; Gohar, A.; Ahmad, N.; Ahmad, M. Haematological profile in cyclic, non-cyclic and endometritic cross-bred cattle. Int. J. Agric. Biol. 2003, 5, 332-334.

101. Aderemi, F.A. Effect of replacement of wheat bran with cassava supplement or un-supplemented with enzyme on the haematology and serum biochemistry of pullet chick. Trop. J. Anim. Sci. 2004, 7, 147-153.

102. Opara, M.N.; Ike, K.A.; Okoli, I.C. Haematology and plasma biochemistry of the wild adult African grasscutter (Thryonomis swinderianus, Temminck). J. Am. Sci. 2006, 2, 17-22.

103. Otto, F.; Vilela, F.; Harun, M.; Taylor, G.; Baggasse, P.; Bogin, E. Biochemical blood profile of Angoni cattle in Mozambique. Israel J. Vet. Med. 2000, 55, 95-102.

104. Babatunde, G.M.; Fajimi, A.O.; Oyejide, A.O. Rubber seed oil versus palm oil in broiler chicken diets. Effects on performance, nutrient digestibility, haematology and carcass characteristics. Anim. Feed Sci. Technol. 1992, 35, 133-146.

105. Grunwaldt, E.G.; Guevara, J.C.; Estevez, O.R.; Vicente, A.; Rousselle, H.; Alcuten, N.; Stasi, C.R. Biochemical and haemato-logical measurements in beef cattle in Mendoza plain rangelands (Argentina). Trop. Anim. Health Prod. 2005, 37, 527-540. [CrossRef]

106. Ndlovu, T.; Chimonyo, M.; Okoh, A.I.; Muchenje, V.; Dzama, K.; Raats, J.G. Assessing the nutritional status of beef cattle: Current practices and future prospects. Afr. J. Biotechnol. 2007, 6, 2727-2734. [CrossRef]

107. Maurya, S.K.; Singh, O.P. Assessment of blood biochemical profile and nutritional status of buffaloes under field conditions. Buffalo Bull. 2015, 34, 161-167.

108. Lee, A.; Twardock, A.; Bubar, R.; Hall, J.; Davis, C. Blood metabolic profiles: Their use and relation to nutritional status of dairy cows. J. Dairy Sci. 1978, 61, 1652-1670. [CrossRef]

109. Campanile, G.; Baruselli, P.; Vecchio, D.; Prandi, A.; Neglia, G.; Carvalho, N.; Sales, J.; Gasparrini, B.; Occhio, M. Growth, metabolic status and ovarian function in buffalo (Bubalus bubalis) heifers fed a low energy or high energy diet. Anim. Reprod. Sci. 2010, 122, 74-81. [CrossRef]

110. Bertoni, G.; Amici, A.; Lombardelli, R.; Bartocci, S. Variations of metabolic profile and hormones in blood of buffaloes, cattle and sheep males fed the same diets. In Publication-European Association for Animal Production; Butterworths: London, UK, 1993; Volume 62, p. 345.

111. Divers, T.J.; Peek, S.F. Rebhun's Diseases of Dairy Cattle; Elsevier Health Sciences: Amsterdam, The Netherlands, 2007.

112. Tiwari, C.; Chandramoni, A.; Jadhao, S.; Gowda, S.; Khan, M. Studies on blood biochemical constituents and rumen fermentation in growing buffalo calves fed ammoniated straw-based rations supplemented with different protein sources. Anim. Feed. Sci. Technol. 2001, 89, 119-130. [CrossRef] 
113. Katiyar, S.; Mudgal, V.; Sharma, R.K.; Jerome, A.; Phulia, S.K.; Balhara, A.K.; Singh, I. Alterations in haemato-biochemical profile following by-pass nutrients supplementation in early lactating Murrah buffaloes. Buffalo Bull. 2019, 38, $203-215$.

114. Ranjan, A.; Sahoo, B.; Singh, V.K.; Srivastava, S.; Singh, S.P.; Pattanaik, A.K. Effect of bypass fat supplementation on productive performance and blood biochemical profile in lactating Murrah (Bubalus bubalis) buffaloes. Trop. Anim. Heal. Prod. 2012, 44, 1615-1621. [CrossRef]

115. Kitagawa, H.; Kitoh, K.; Ito, T.; Ohba, Y.; Nishii, N.; Katoh, K.; Obara, Y.; Motoi, Y.; Sasaki, Y. Serum growth hormone and insulin-like growth factor-1 concentrations in Japanese black cattle with growth retardation. J. Vet. Med. Sci. 2001, 63, 167-170. [CrossRef]

116. Agudelo-Gómez, D.; Hurtado-Lugo, N.; Cerón-Muñoz, M.F. Growth curves and genetic parameters in colombian buffaloes (Bubalus bubalis Artiodactyla, Bovidae). Rev. Colomb. Cienc. Pec. 2009, 22, 178-188.

117. Sørensen, M.; Chaudhuri, S.; Louveau, I.; Coleman, M.; Etherton, T. Growth hormone binding proteins in pig adipose tissue: Number, size and effects of pGH treatment on pGH and bGH binding. Domest. Anim. Endocrinol. 1992, 9, 13-24. [CrossRef]

118. Baumann, G. Growth hormone-binding proteins: State of the art. J. Endocrinol. 1994, 141, 1-6. [CrossRef]

119. Renaville, R.; Hammadi, M.; Portetelle, D. Role of the somatotropic axis in the mammalian metabolism. Domest. Anim. Endocrinol. 2002, 23, 351-360. [CrossRef]

120. Gao, X.; Xu, X.-R.; Ren, H.-Y.; Zhang, Y.-H.; Xu, S.-Z. The effects of the GH, IGF-I and IGF-IBP3 gene on growth and development traits of Nanyang cattle in different growth period. Yi Chuan Hered. 2006, 28, 927-932.

121. Othman, O.E.M.; Alam, S.S.; El-Aziem, S.H.A. Single nucleotide polymorphism in Egyptian cattle insulin-like growth factor binding protein-3 gene. J. Genet. Eng. Biotechnol. 2014, 12, 143-147. [CrossRef]

122. Ayuk, J.; Sheppard, M.C. Growth hormone and its disorders. Postgrad. Med. J. 2006, 82, 24-30. [CrossRef] [PubMed]

123. Akis, I.; Oztabak, K.; Gonulalp, I.; Mengi, A.; Un, C. IGF-1 and IGF-1R gene polymorphisms in East Anatolian Red and South Anatolian Red cattle breeds. Генетика 2010, 46, 439-442. [CrossRef]

124. Giovannucci, E.; Pollak, M.; Liu, Y.; Platz, E.A.; Majeed, N.; Rimm, E.B.; Willett, W.C. Nutritional predictors of insulin-like growth factor I and their relationships to cancer in men. Cancer Epidemiol. Biomark. Prev. 2003, 12, 84-89.

125. Clemmons, D.R.; Klibanski, A.; Underwood, L.E.; McArthur, J.W.; Ridgway, E.C.; Beitins, I.Z.; Van Wyk, J.J. Reduction of plasma immunoreactive somatomedin C during fasting in humans. J. Clin. Endocrinol. Metab. 1981, 53, 1247-1250. [CrossRef]

126. Merimee, T.J.; Zapf, J.; Froesch, E.R. Insulin-like growth factors in the fed and fasted states. J. Clin. Endocrinol. Metab. 1982, 55, 999-1002. [CrossRef]

127. Ho, K.Y.; Veldhuis, J.D.; Johnson, M.L.; Furlanetto, R.; Evans, W.S.; Alberti, K.G.; Thorner, M.O. Fasting enhances growth hormone secretion and amplifies the complex rhythms of growth hormone secretion in man. J. Clin. Investig. 1988, 81, 968-975. [CrossRef]

128. Thissen, J.-P.; Ketelslegers, J.-M.; Underwood, L.E. Nutritional regulation of the insulin-like growth factors. Endocr. Rev. 1994, 15, 80-101. [CrossRef]

129. Clemmons, D.R.; Seek, M.M.; Underwood, L.E. Supplemental essential amino acids augment the somatomedin-C/insulin-like growth factor I response to refeeding after fasting. Metabolism 1985, 34, 391-395. [CrossRef]

130. Shao, B.; Long, R.; Ding, Y.; Wang, J.; Ding, L.; Wang, H. Morphological adaptations of yak (Bos grunniens) tongue to the foraging environment of the Qinghai-Tibetan Plateau1. J. Anim. Sci. 2010, 88, 2594-2603. [CrossRef]

131. Qiu, Q.; Zhang, G.; Ma, T.; Qian, W.; Wang, J.; Ye, Z.; Cao, C.; Hu, Q.; Kim, J.; Larkin, D.M.; et al. The yak genome and adaptation to life at high altitude. Nat. Genet. 2012, 44, 946-949. [CrossRef]

132. Zhang, Z.; Xu, D.; Wang, L.; Hao, J.; Wang, J.; Zhou, X.; Wang, W.; Qiu, Q.; Huang, X.; Zhou, J.; et al. Convergent evolution of rumen microbiomes in high-altitude mammals. Curr. Biol. 2016, 26, 1873-1879. [CrossRef]

133. Khan, S.; Singh, M.; Mehla, R.K.; Thakur, S.; Meena, B. Plasma hormones and milk production performances in early lactation buffaloes supplemented with a mixture of prilled fat, sweetener and toxin binder. Biotehnol. Stocarstou 2016, 32, 15-26. [CrossRef]

134. Church, D.C. Ruminant Animal: Digestive Physiology and Nutrition; Prentice-Hall: Eaglewood Cliffs, NJ, USA, $1993 ;$ p. 564.

135. Getachew, G.; DePeters, E.J.; Robinson, P.H.; Fadel, J.G. Use of an in vitro rumen gas production technique to evaluate mi-crobial fermentation of ruminant feeds and its impact on fermentation products. Anim. Feed Sci. Technol. 2005, 123, 547-559. [CrossRef]

136. Calabro, S.; Piccolo, V.; Infascelli, F. Evaluation of diet for buffalo dairy cows using the Cornell Net Carbohydrate and Protein System. Asian Australas. J. Anim. Sci. 2003, 16, 1475-1481. [CrossRef]

137. Smith, D.; Smith, T.; Rude, B.; Ward, S. Short communication: Comparison of the effects of heat stress on milk and component yields and somatic cell score in Holstein and Jersey cows. J. Dairy Sci. 2013, 96, 3028-3033. [CrossRef]

138. Iqbal, M.W.; Zhang, Q.; Yang, Y.; Li, L.; Zou, C.; Huang, C.; Lin, B. Comparative study of rumen fermentation and microbial community differences between water buffalo and Jersey cows under similar feeding conditions. J. Appl. Anim. Res. 2017, 46, 740-748. [CrossRef]

139. Chanthakhoun, V.; Wanapat, M.; Kongmun, P.; Cherdthong, A. Comparison of ruminal fermentation characteristics and microbial population in swamp buffalo and cattle. Livest. Sci. 2012, 143, 172-176. [CrossRef]

140. Wanapat, M.; Puramongkon, T.; Siphuak, W. Feeding of cassava hay for lactating dairy cows. Asian Australas. J. Anim. Sci. 2000, 13, 478-482. [CrossRef]

141. Gurbuz, Y.; Davies, D.R. Organic matter digestibility and condensed tannin content of some hybrid sorghum. Anim. Nutr. Feed Technol. 2010, 10, 19-28. 
142. Broderick, G. Effects of varying dietary protein and energy levels on the production of lactating dairy cows. J. Dairy Sci. 2003, 86, 1370-1381. [CrossRef]

143. Wang, C.; Liu, Q.; Guo, G.; Huo, W.; Ma, L.; Zhang, Y.; Pei, C.; Zhang, S.; Wang, H. Effects of dietary supplementation of rumen-protected folic acid on rumen fermentation, degradability and excretion of urinary purine derivatives in growing steers. Arch. Anim. Nutr. 2016, 70, 441-454. [CrossRef]

144. Kang, S.; Wanapat, M.; Phesatcha, K.; Norrapoke, T. Effect of protein level and urea in concentrate mixture on feed intake and rumen fermentation in swamp buffaloes fed rice straw-based diet. Trop. Anim. Heal. Prod. 2015, 47, 671-679. [CrossRef] [PubMed]

145. Bi, Y.; Zeng, S.; Zhang, R.; Diao, Q.; Tu, Y. Effects of dietary energy levels on rumen bacterial community composition in Holstein heifers under the same forage to concentrate ratio condition. BMC Microbiol. 2018, 18, 1-11. [CrossRef]

146. Van Houtert, M. Challenging the rational for altering VFA ratios in growing ruminants. Feed Mix 1996, 4, 8-11.

147. Chesson, A.; Forsberg, C.W. Polysaccharide degradation by rumen microorganisms. In The Rumen Microbial Ecosystem; Springer Science and Business Media LLC: Berlin, Germany, 1997; pp. 329-381.

148. Sutton, J.D.; Morant, S.V.; Bines, J.A.; Napper, D.J.; Givens, D.I. Effect of altering the starch: Fibre ratio in the concentrates on hay intake and milk production by Friesian cows. J. Agric. Sci. 1993, 120, 379-390. [CrossRef]

149. McCarthy, R.D., Jr.; Klusmeyer, T.H.; Vicini, J.L.; Clark, J.H.; Nelson, D.R. Effects of source of protein and carbohydrate on ruminal fermentation and passage of nutrients to the small intestine of lactating cows. J. Dairy Sci. 1989, 72, 2002-2016. [CrossRef]

150. Kolver, E.; De Veth, M. Prediction of ruminal pH from pasture-based diets. J. Dairy Sci. 2002, 85, 1255-1266. [CrossRef]

151. Oh, Y.-K.; Kim, J.-H.; Kim, K.-H.; Choi, C.-W.; Kang, S.-W.; Nam, I.-S.; Kim, D.-H.; Song, M.-K.; Kim, C.-W.; Park, K.-K. Effects of level and degradability of dietary protein on ruminal fermentation and concentrations of soluble non-ammonia nitrogen in ruminal and omasal digesta of Hanwoo steers. Asian Australas. J. Anim. Sci. 2008, 21, 392-403. [CrossRef]

152. Da Silva, L.; Pereira, O.; Da Silva, T.; Filho, S.V.; Ribeiro, K. Effects of silage crop and dietary crude protein levels on digestibility, ruminal fermentation, nitrogen use efficiency, and performance of finishing beef cattle. Anim. Feed. Sci. Technol. 2016, 220, 22-33. [CrossRef]

153. Reynolds, C.K.; Kristensen, N.B. Nitrogen recycling through the gut and the nitrogen economy of ruminants: An asynchronous symbiosis. J. Anim. Sci. 2008, 86, 293-305. [CrossRef]

154. Reynal, S.; Broderick, G. Effect of dietary level of rumen-degraded protein on production and nitrogen metabolism in lactating dairy cows. J. Dairy Sci. 2005, 88, 4045-4064. [CrossRef]

155. Budi, T.; Budi, S.; Elizabeth, W. Protected fat: Preparation and digestibility. In Proceedings of the Workshop on Advances in Small Ruminant Research, Ciawi, Indonesia, 3-4 August 1993; pp. 3-4.

156. Naik, P.K.; Saijpaul, S.; Rani, N. Effect of ruminally protected fat on in vitro fermentation and apparent nutrient digestibility in buffaloes (Bubalus bubalis). Anim. Feed. Sci. Technol. 2009, 153, 68-76. [CrossRef]

157. Saijpaul, S.; Naik, P.K.; Rani, N. Effects of rumen protected fat on in vitro dry matter degradability of dairy rations. Indian J. Anim. Sci. 2010, 80, 993.

158. Chalupa, W.; Vecchiarelli, B.; Elser, A.E.; Kronfeld, D.; Sklan, D.; Palmquist, D.L. Ruminal fermentation in vivo as influenced by long-chain fatty acids. J. Dairy Sci. 1986, 69, 1293-1301. [CrossRef]

159. Ohajuruka, O.A.; Zhigou, W.U.; Palmquist, D.L. Ruminal metabolism, fiber and protein digestion by lactating dairy cows fed calcium soap or animal vegetable fat. J. Dairy Sci. 1991, 74, 2601-2609. [CrossRef]

160. Schauff, D.; Clark, J. Effects of feeding diets containing calcium salts of long-chain fatty acids to lactating dairy cows. J. Dairy Sci. 1992, 75, 2990-3002. [CrossRef]

161. Guan, L.L.; Nkrumah, J.D.; Basarab, J.A.; Moore, S.S. Linkage of microbial ecology to phenotype: Correlation of rumen mi-crobial ecology to cattle's feed efficiency. FEMS Microbiol. Lett. 2008, 288, 85-91. [CrossRef]

162. Carberry, C.A.; Kenny, D.A.; Han, S.; McCabe, M.S.; Waters, S.M. Effect of phenotypic residual feed intake and dietary forage content on the rumen microbial community of beef cattle. Appl. Environ. Microbiol. 2012, 78, 4949-4958. [CrossRef]

163. Bevans, D.W.; Beauchemin, K.A.; Schwartzkopf-Genswein, K.S.; McKinnon, J.J.; McAllister, T.A. Effect of rapid or gradual grain adaptation on subacute acidosis and feed intake by feedlot cattle1,2. J. Anim. Sci. 2005, 83, 1116-1132. [CrossRef]

164. Russell, J.B.; Rychlik, J.L. Factors that alter rumen microbial ecology. Science 2001, 292, 1119-1122. [CrossRef]

165. Makkar, H.P.; Beever, D. Optimization of feed use efficiency in ruminant production systems. In Proceedings of the FAO Symposium, Bangkok, Thailand, 27 November 2012; FAO Animal Production and Health Division: Rome, Italy, 2013.

166. Cui, K.; Qi, M.; Wang, S.; Diao, Q.; Zhang, N. Dietary energy and protein levels influenced the growth performance, ruminal morphology and fermentation and microbial diversity of lambs. Sci. Rep. 2019, 9, 16612. [CrossRef]

167. Dahllöf, I.; Baillie, H.; Kjelleberg, S. rpoB-based microbial community analysis avoids limitations inherent in $16 \mathrm{~s}$ rRna gene intraspecies heterogeneity. Appl. Environ. Microbiol. 2000, 66, 3376-3380. [CrossRef]

168. Faniyi, T.O.; Adegbeye, M.J.; Elghandour, M.; Pilego, A.B.; Salem, A.Z.; Olaniyi, T.A.; Adediran, O.; Adewumi, M.K. Role of diverse fermentative factors towards microbial community shift in ruminants. J. Appl. Microbiol. 2019, 127, 2-11. [CrossRef]

169. Fernando, S.C.; Purvis, H.T.; Najar, F.Z.; Sukharnikov, L.O.; Krehbiel, C.R.; Nagaraja, T.G.; Roe, B.A.; DeSilva, U. Rumen microbial population dynamics during adaptation to a high-grain diet. Appl. Environ. Microbiol. 2010, 76, 7482-7490. [CrossRef]

170. De Menezes, A.B.; Lewis, E.; O’Donovan, M.; O’Neill, B.F.; Clipson, N.; Doyle, E.M. Microbiome analysis of dairy cows fed pasture or total mixed ration diets. FEMS Microbiol. Ecol. 2011, 78, 256-265. [CrossRef] 
171. Petri, R.M.; Schwaiger, T.; Penner, G.B.; Beauchemin, K.A.; Forster, R.J.; McKinnon, J.J.; McAllister, T.A. Characterization of the core rumen microbiome in cattle during transition from forage to concentrate as well as during and after an acidotic challenge. PLoS ONE 2013, 8, e83424. [CrossRef]

172. Goad, D.W.; Goad, C.L.; Nagaraja, T.G. Ruminal microbial and fermentative changes associated with experimentally induced subacute acidosis in steers. J. Anim. Sci. 1998, 76, 234-241. [CrossRef]

173. Tajima, K.; Aminov, R.I.; Nagamine, T.; Matsui, H.; Nakamura, M.; Benno, Y. Diet-dependent shifts in the bacterial population of the rumen revealed with real-time PCR. Appl. Environ. Microbiol. 2001, 67, 2766-2774. [CrossRef]

174. Koike, S.; Kobayashi, Y. Development and use of competitive PCR assays for the rumen cellulolytic bacteria: Fibrobacter succinogenes, Ruminococcus albus and Ruminococcus flavefaciens. FEMS Microbiol. Lett. 2001, 204, 361-366. [CrossRef]

175. Mrazek, J.; Tepšič, K.; Avguštin, G.; Kopečný, J. Diet-dependent shifts in ruminal butyrate-producing bacteria. Folia Microbiol. 2006, 51, 294-298. [CrossRef]

176. Vinh, N.; Wanapat, M.; Khejornsar, P.; Kongmun, P. Studies of diversity of rumen microorganisms and fermentation in swamp buffalo fed different diets. J. Anim. Veter. Adv. 2011, 10, 406-414. [CrossRef]

177. Liu, Q.; Wang, C.; Pei, C.; Li, H.; Wang, Y.; Zhang, S.; He, J.; Wang, H.; Yang, W.; Bai, Y.; et al. Effects of isovalerate supplementation on microbial status and rumen enzyme profile in steers fed on corn stover based diet. Livest. Sci. 2014, 161, 60-68. [CrossRef]

178. Wang, C.; Liu, Q.; Guo, G.; Huo, W.J.; Liang, Y.; Pei, C.X.; Wang, H. Effects of different dietary protein levels and rumen-protected folic acid on ruminal fermentation, degradability, bacterial populations and urinary excretion of purine derivatives in beef steers. J. Agric. Sci. 2017, 155, 1477-1486. [CrossRef]

179. Yang, C.-T.; Si, B.-W.; Diao, Q.-Y.; Jin, H.; Zeng, S.-Q.; Tu, Y. Rumen fermentation and bacterial communities in weaned Chahaer lambs on diets with different protein levels. J. Integr. Agric. 2016, 15, 1564-1574. [CrossRef]

180. Nardone, A.; Valfrè, F. Effects of changing production methods on quality of meat, milk and eggs. Livest. Prod. Sci. 1999, 59, 165-182. [CrossRef]

181. Rao, V.A.; Thulasi, G.; Ruban, S.W.; Thangaraju, P. Optimum age of slaughter of non-descript buffalo: Carcass and yield characteristics. J. Agric. Sci. 2009, 42, 133-138.

182. Anjaneyulu, A.S.R.; Sengar, S.S.; Lakshmanan, V.; Joshi, D.C. Meat quality of male buffalo calves maintained on different levels of protein. Buffalo Bull. 1985, 4, 45-47.

183. De La Torre, A.; Debiton, E.; Juanéda, P.; Durand, D.; Chardigny, J.-M.; Barthomeuf, C.; Bauchart, D.; Gruffat, D. Beef conjugated linoleic acid isomers reduce human cancer cell growth even when associated with other beef fatty acids. Br. J. Nutr. 2006, 95, 346-352. [CrossRef]

184. Issanchou, S. Consumer expectations and perceptions of meat and meat product quality. Meat Sci. 1996, 43, 5-19. [CrossRef]

185. Miller, R.K. Factors affecting the quality of raw meat. In Meat Processing: Improving Quality; Woodhead Publishing: Cambridge, UK, 2002; pp. 27-63.

186. Webb, E.C. Carcass fat quality and composition. In Consistency of Quality: Proceedings of the 11th International Meat Symposium, Centurion, South Africa, 29-30 January 2003; Agricultural Research Council: Irene, South Africa, 2003; pp. 48-55.

187. Wood, J.D.; Enser, M.; Fisher, A.V.; Nute, G.R.; Sheard, P.R.; Richardson, R.I.; Hughes, S.I.; Whittington, F.M. Fat deposition, fatty acid composition and meat quality: A review. Meat Sci. 2008, 78, 343-358. [CrossRef]

188. Webb, E.C. Manipulating beef quality through feeding. South Afr. J. Food Sci. Nutr. 2006, 7, 1-24.

189. Infascelli, F.; Roscia, M.; Buffardi, F. La Carne di Bufalo; Edizioni Pubblicità Italia: Rome, Italy, 2009.

190. Al-Jammas, M.; Agabriel, J.; Vernet, J.; Ortigues-Marty, I. The chemical composition of carcasses can be predicted from proxy traits in finishing male beef cattle: A meta-analysis. Meat Sci. 2016, 119, 174-184. [CrossRef]

191. Lambertz, C.; Panprasert, P.; Holtz, W.; Moors, E.; Jaturasitha, S.; Wicke, M.; Gauly, M. Carcass characteristics and meat quality of swamp buffaloes (Bubalus bubalis) fattened at different feeding intensities. Asian Australas. J. Anim. Sci. 2014, 27, 551-560. [CrossRef]

192. Manso, T.; Castro, T.; Mantecón, A.; Jimeno, V. Effects of palm oil and calcium soaps of palm oil fatty acids in fattening diets on digestibility, performance and chemical body composition of lambs. Anim. Feed. Sci. Technol. 2006, 127, 175-186. [CrossRef]

193. Velasco, S.; Cañeque, V.; Pérez, C.; Lauzurica, S.; Díaz, M.; Huidobro, F.; Manzanares, C.; González, J. Fatty acid composition of adipose depots of suckling lambs raised under different production systems. Meat Sci. 2001, 59, 325-333. [CrossRef] 